\title{
3.3-million-year-old stone tools from Lomekwi 3, West Turkana, Kenya
}

Sonia Harmand ${ }^{1,2,3}$, Jason E. Lewis ${ }^{1,3,4}$, Craig S. Feibel ${ }^{3,4,5}$, Christopher J. Lepre ${ }^{3,5,6}$, Sandrine Prat ${ }^{3,7}$, Arnaud Lenoble $^{3,8}$, Xavier Boës ${ }^{3,7}$, Rhonda L. Quinn ${ }^{3,5}$, Michel Brenet ${ }^{8,10}$, Adrian Arroyo ${ }^{2}$, Nicholas Taylor ${ }^{2,3}$, Sophie Clément ${ }^{3,11}$, Guillaume Daver ${ }^{12}$, Jean-Philip Brugal ${ }^{3,13}$, Louise Leakey ${ }^{1}$, Richard A. Mortlock ${ }^{5}$, James D. Wright ${ }^{5}$, Sammy Lokorodi ${ }^{3}$, Christopher Kirwa ${ }^{3,14}$, Dennis V. Kent ${ }^{5,6}$ \& Hélène Roche ${ }^{2,3}$

Human evolutionary scholars have long supposed that the earliest stone tools were made by the genus Homo and that this technological development was directly linked to climate change and the spread of savannah grasslands. New fieldwork in West Turkana, Kenya, has identified evidence of much earlier hominin technological behaviour. We report the discovery of Lomekwi 3, a 3.3-million-year-old archaeological site where in situ stone artefacts occur in spatiotemporal association with Pliocene hominin fossils in a wooded palaeoenvironment. The Lomekwi 3 knappers, with a developing understanding of stone's fracture properties, combined core reduction with battering activities. Given the implications of the Lomekwi 3 assemblage for models aiming to converge environmental change, hominin evolution and technological origins, we propose for it the name 'Lomekwian', which predates the Oldowan by 700,000 years and marks a new beginning to the known archaeological record.

Conventional wisdom in human evolutionary studies has assumed that the origins of hominin sharp-edged stone tool production were linked to the emergence of the genus $\mathrm{Homo}^{1,2}$ in response to climate change and the spread of savannah grasslands ${ }^{3,4}$. In 1964, fossils looking more like later Homo than australopithecines were discovered at Olduvai Gorge (Tanzania) in association with the earliest known stone tool culture, the Oldowan, and so were assigned to the new species: Homo habilis or 'handy man'. The premise was that our lineage alone took the cognitive leap of hitting stones together to strike off sharp flakes and that this was the foundation of our evolutionary success. Subsequent discoveries pushed back the date for the first Oldowan stone tools to 2.6 million years ago ${ }^{5,6}(\mathrm{Ma})$ and the earliest fossils attributable to early Homo to only $2.4-2.3 \mathrm{Ma}^{7,8}$, opening up the possibility of tool manufacture by hominins other than $\mathrm{Homo}^{9}$ before $2.6 \mathrm{Ma}^{10-12}$.

The earliest known artefacts from the sites of Gona $(\sim 2.6 \mathrm{Ma})^{6,12}$, Hadar $\left(2.36 \pm 0.07 \mathrm{Ma}^{13}\right)$, and Omo $\left(2.34 \pm 0.04 \mathrm{Ma}^{14}\right)$ in Ethiopia, and especially Lokalalei $2 \mathrm{C}\left(2.34 \pm 0.05 \mathrm{Ma}^{15}\right)$ in Kenya, demonstrate that these hominin knappers already had considerable abilities in terms of planning depth, manual dexterity and raw material selectivity ${ }^{14-19}$. Cut-marked bones from Dikika, Ethiopia ${ }^{20}$, dated at $3.39 \mathrm{Ma}$, has added to speculation on pre-2.6-Ma hominin stone tool use. It has been argued that percussive activities other than knapping, such as the pounding and/or battering of plant foods or bones, could have been critical components of an even earlier, as-yet-unrecognized, stage of hominin stone tool use $\mathrm{e}^{21-25}$. Any such artefacts may have gone unrecognized if they do not directly resemble known Oldowan lithics, occur at very low densities or were made of perishable materials ${ }^{10}$.

In 2011, the West Turkana Archaeological Project (WTAP) began an archaeological survey and excavation in the Lomekwi Member ${ }^{26}$
(3.44-2.53 Ma) of the Nachukui Formation (west of Lake Turkana, northern Kenya; Fig. 1) to search for evidence of early hominin lithic behaviour. Several promising surface artefact concentrations and dispersed single finds were discovered. At the Lomekwi 3 archaeological site, 28 lithic artefacts were initially found lying on the surface or within a slope deposit, and one core was uncovered in situ. By the close of the subsequent 2012 field season, excavation at LOM3 had reached $13 \mathrm{~m}^{2}$, revealing an additional 18 stone tools and 11 fossils in situ (Extended Data Table 1) within a horizon (approximately $80 \mathrm{~cm}$ ) of indurated sandy-granular sediments stratified in a thick bed of fine silts (Fig. 2). A further 100 lithic artefacts and 22 fossil remains were collected from the surface immediately around the site along with two artefacts from the slope deposit (Extended Data Fig. 1). These finds occur in the same geographic and chronological range as the paratype of Kenyanthropus platyops (KNM-WT 38350) ${ }^{27}$, other hominin fossils generally referred to cf. K. platyops ${ }^{28}$, and one unpublished hominin tooth (KNM-WT 64060) found by WTAP in 2012 (Supplementary Information, part A and Supplementary Table 1).

\section{Geochronological and palaeoenvironmental contexts}

The chronological context of LOM3 derives from correlation with the Lomekwi Member of the Nachukui Formation ${ }^{26}$ and radiometrically dated tuffs within $\mathrm{it}^{29,30}$, as well as from magnetostratigraphy of the site and estimated sedimentation rates. The composite type section of the Lomekwi Member, $2-5 \mathrm{~km}$ east of LOM3, is bracketed by the $\alpha$-Tulu Bor Tuff $(3.44 \pm 0.02 \mathrm{Ma})$ at the base and the Lokalalei Tuff $(2.53 \pm 0.02 \mathrm{Ma})$ at the top ${ }^{29,30}$. Closer to LOM3, two new sections provide additional context. Section 1 (CSF 2011-1; $\sim 46 \mathrm{~m}$ thick, located 1.44 to $1 \mathrm{~km}$ north of LOM3, Extended Data Fig. 2) includes

\footnotetext{
${ }^{1}$ Turkana Basin Institute, Stony Brook University, Stony Brook, New York 11794-4364, USA. ${ }^{2}$ CNRS, UMR 7055, Préhistoire et Technologie, Université Paris Ouest Nanterre La Défense, 21 allée de

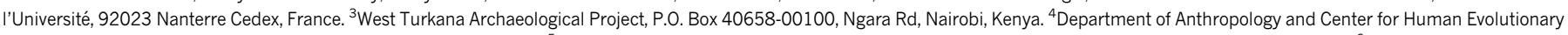
Studies, Rutgers University, New Brunswick, New Jersey 08901, USA. ${ }^{5}$ Department of Earth and Planetary Sciences, Rutgers University, Piscataway, New Jersey 08854, USA. ${ }^{6}$ Lamont-Doherty Earth

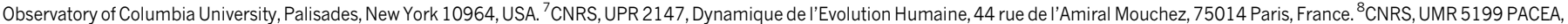

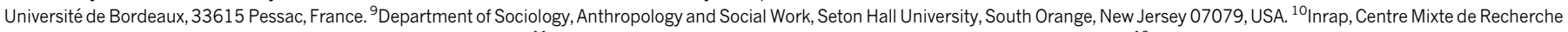

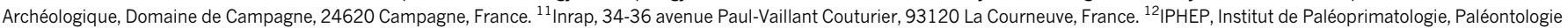

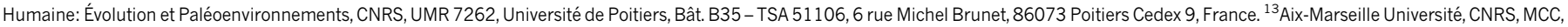
UMR 7269, LAMPEA, 13094 Aix-en-Provence Cedex 2, France. ${ }^{14}$ National Museums of Kenya, Department of Earth Sciences, Archaeology Section, P.O. Box 40658-00100 Ngara Rd, Nairobi, Kenya.
} 


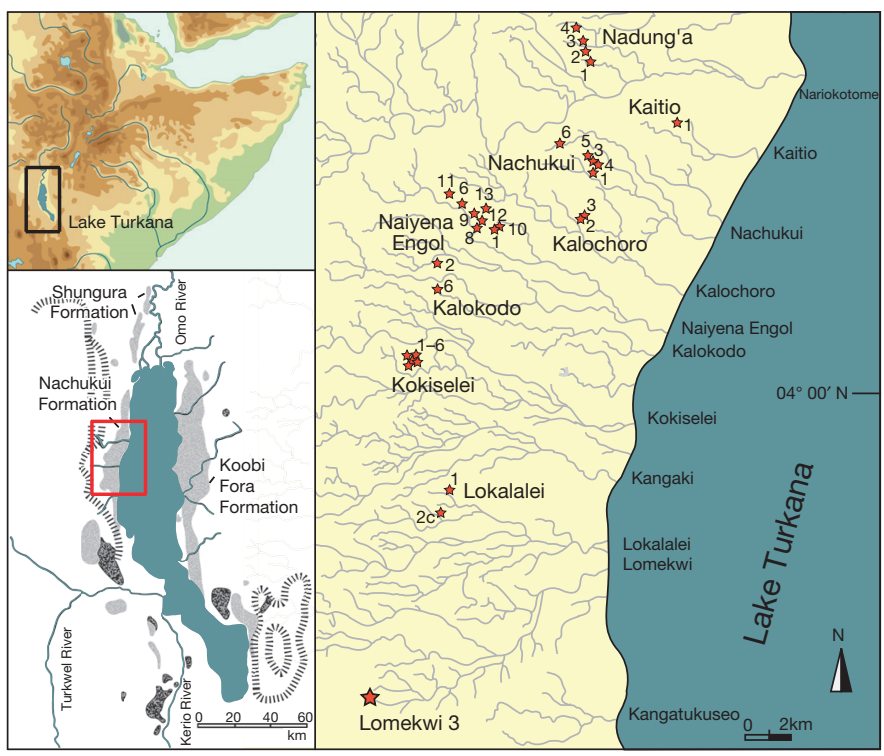

Figure $1 \mid$ Geographic location of the LOM3 site. Map showing relation of LOM3 to other West Turkana archaeological site complexes.

the $\alpha$ - and $\beta$-Tulu Bor Tuffs in the lower third (Supplementary Information, part B). Composite Section 2 (upper CSF-2012-9, $\sim 44 \mathrm{~m}$ thick, located $0.4 \mathrm{~km}$ south of LOM3 and lower CSF-2011-2 located $0.28 \mathrm{~km}$ north of LOM3, Fig. 3a, b and Extended Data Fig. 2) includes at the base a lenticular tuff correlated geochemically with the Toroto Tuff in the Koobi Fora Formation where it outcrops 10-12 m above the $\alpha$-Tulu Bor Tuff, and has been dated radiometrically to $3.31 \pm 0.02$ (refs 29, 30). Both the two Tulu Bor Tuffs in Section 1 and the Toroto Tuff in Section 2 occur in normal polarity magnetozones, corresponding to the early part of the Gauss Chron C2An (Fig. 3a and Supplementary Information, part C), while the overlying sediments at both sites are in reversed polarity zones as are the sediments encompassing the in situ artefacts at LOM3, $10 \mathrm{~m}$ above the Toroto Tuff (Fig. 3b). Thus, the artefacts were deposited after $3.31 \pm 0.02 \mathrm{Ma}$ during the Mammoth reverse subchron C2An.2r $\left(3.33-3.21 \mathrm{Ma}^{31}\right)$. Based on extrapolation of sediment accumulation rates between the levels of the $\alpha$-Tulu Bor and Toroto Tuffs and the onset of subchron C2An.2r, an age of 3.3 Ma is determined for LOM3 (Extended Data Fig. 3 and Supplementary Information, part C), which accords with previous interpretations of the antiquity of fossils from this locality ${ }^{27-30}$.

Stable carbon isotopic analyses of pedogenic carbonate nodules located adjacent to and at LOM3 yielded a mean $\delta^{13} \mathrm{C}_{\mathrm{VPDB}}$ value of $-7.3 \pm 1.1 \%$ (Extended Data Fig. 4 and Supplementary Information, part D), which indicates a mean fraction of woody cover $\left(f_{\mathrm{wc}}\right)$ of $47 \pm 9 \%$ and positions the site within a woodland/bushland/thicket/ shrubland environment ${ }^{32}$. Our results are comparable to paleosol $\delta^{13} \mathrm{C}_{\mathrm{VPDB}}$ values of other East African hominin environments between 3.2 and 3.4 Ma but significantly woodier than the $2.6 \mathrm{Ma}$ artefact site at Gona, Ethiopia (Extended Data Figs $4 b, c)^{32,33}$. The associated fauna supports this interpretation (Supplementary Information, part E).

\section{The Lomekwi 3 site}

The LOM3 site is a low hill eroded into by a small ravine. The uppermost sediments encountered during excavation form a plaque of slope deposit which is a few centimetres thick (Fig. 2a). Under it, a series of interdigitated lenses of sands, granules and silts are found. They correspond to different facies of the same sedimentary environment related to the distal fan deposit in which the artefacts are preserved (Fig. 2c and Supplementary Information, part B). Sealed in situ in these Pliocene sediments (Extended Data Fig. 5), the LOM3 archaeological material is considered to be in a slightly re-distributed primary

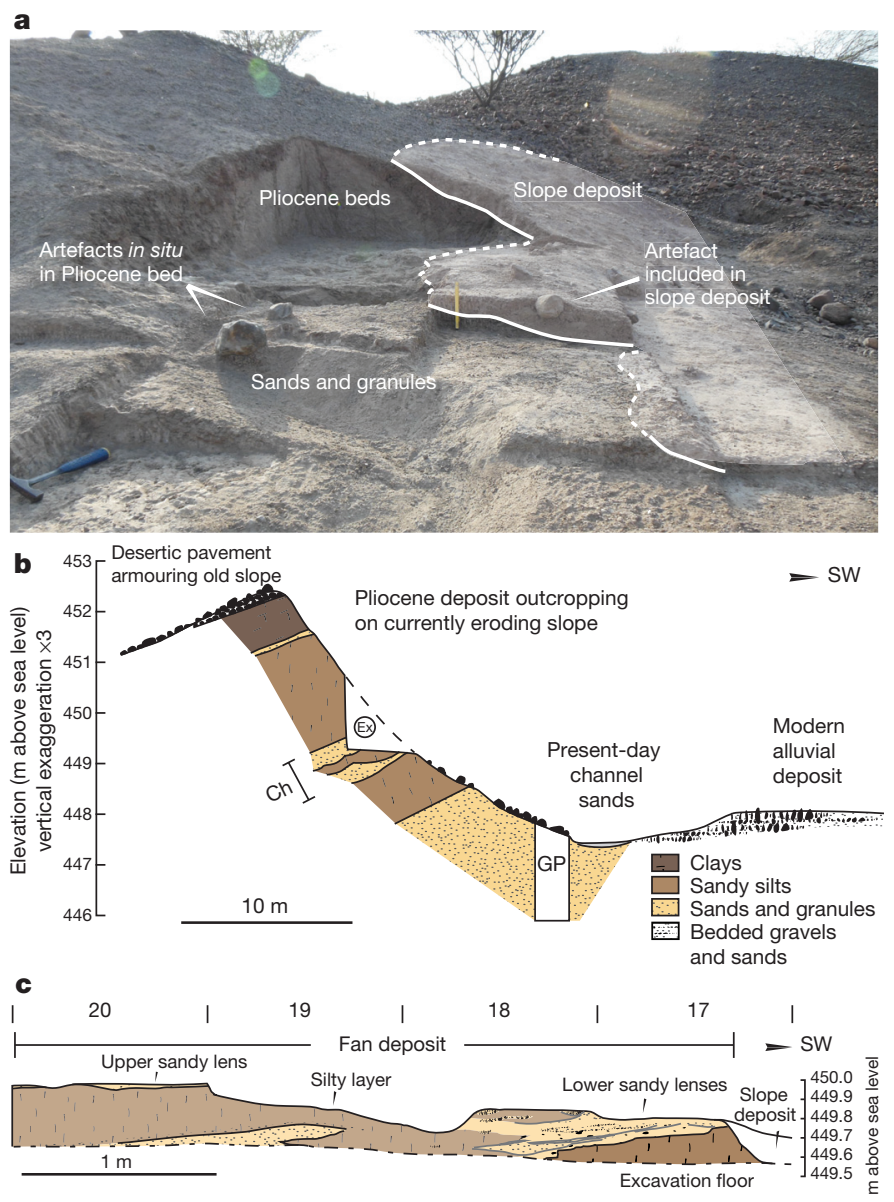

Figure $2 \mid$ LOM3 lithological context. a, View of the excavation, facing east, showing relationship between surface, slope deposit, and in situ contexts containing the artefacts and fossils. Scale in midground is $20 \mathrm{~cm}$. Lowerleftmost artefact is the anvil LOM3-2012-K18-2, shown in Fig. 5a. b, Topographic profile and stratigraphic units at site level showing the excavation zone (Ex), the geological trench made at the base of the section (GP); the artefacts and fossils derive from a series of lenses of sand and granules making up a $\sim 1 \mathrm{~m}$ thick bed (Ch).c, Section at the excavation along bands I and $\mathrm{J}$ (indicated by the black line in Extended Data Fig. 1a) showing the sediments which form the fan deposits containing the artefacts.

archaeological context based on the following observations: (1) artefacts of different sizes, ranging from $\sim 1 \mathrm{~cm}$ wide flake fragments to very large worked cobbles and cores are present; (2) artefacts are larger and heavier than could be carried by the energy of the alluvial system that deposited the sediments (the maximal competence of the transport flow can be inferred by the coarsest fraction of the bed load deposited, that is, $<4 \mathrm{~cm}$ diameter granules); (3) many excavated lithic pieces exhibit only slight abrasion, as reflected in the observation of arête and edge widths measuring $\leq 100 \mu \mathrm{m}$. Moreover, although it is not possible at present to link all surface finds to the excavated context, the identification of a refit between a core recovered from the dense stratified deposit and one surface flake clearly shows that at least a portion of the surface material derives directly from the in situ level (Fig. 4a). More precise interpretation of site preservation is based on observations drawn from the excavation, with the most plausible possibilities limited to either good preservation of the site and most of the assemblage, or a slight redistribution in close proximity of the original activity location (Supplementary Information, part B).

\section{Technology of the Lomekwi 3 stone tools}

Based on the lithic material recovered in 2011 and 2012, the current total assemblage ( $n=149$ surface and in situ artefacts) incorporates 

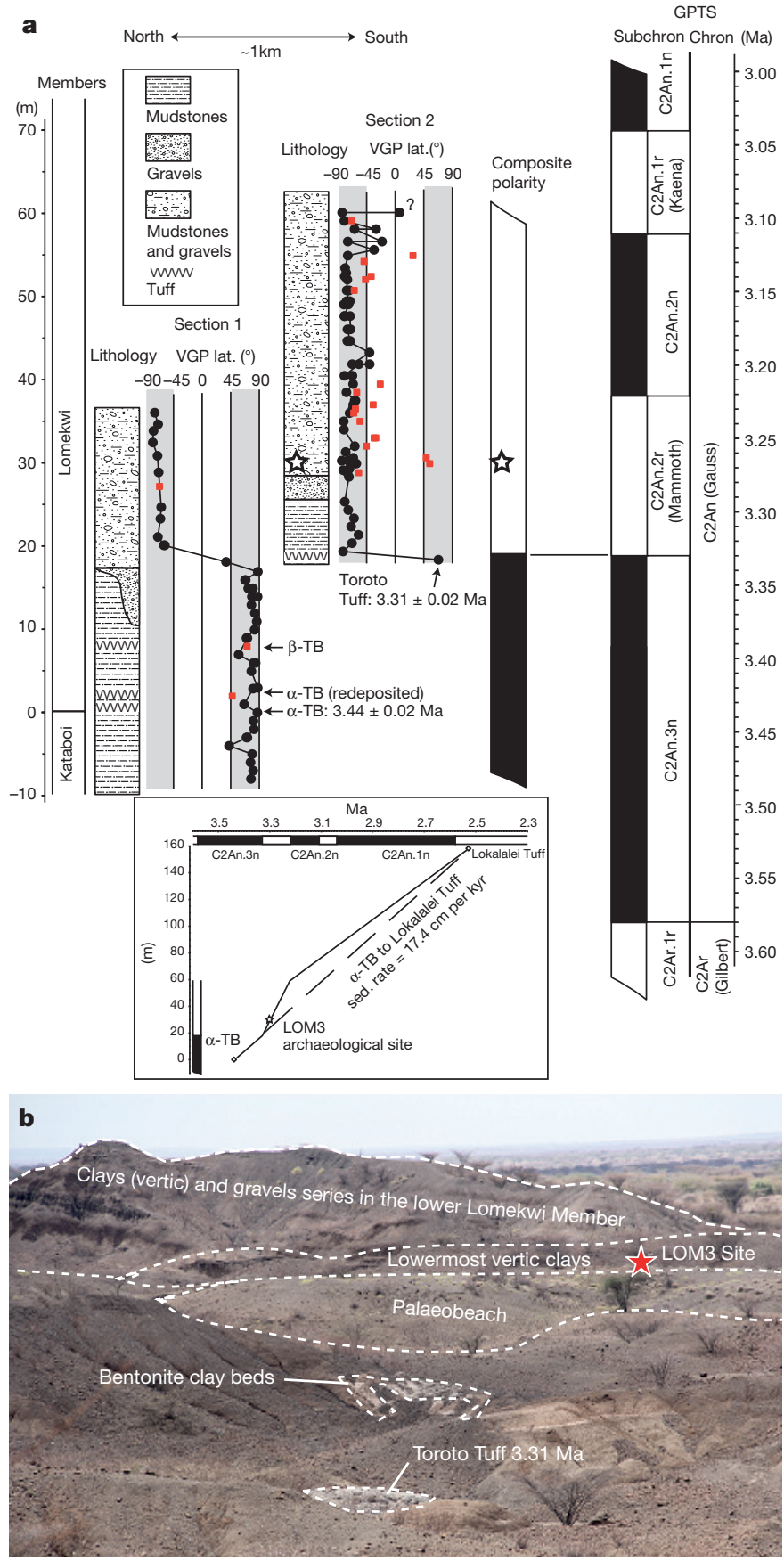

Figure 3 Chronostratigraphic framework for LOM3.

a, Chronostratigraphic framework for LOM3 (star) with generalized stratigraphic columns and magnetostratigraphic alignment to the geomagnetic polarity time scale (GPTS) in context of dates of tuffaceous markers ( \pm 1 s.d.) and stratigraphic nomenclature for Members of the Nachukui Formation ${ }^{26,30}$. A linearly interpolated date of 3.3 Ma for the in situ stone tools is consistent with the site's magnetostratigraphic position within the reverse polarity interval that is correlated to reverse subchron C2An.2r (Mammoth Subchron) dated at 3.33-3.21 $\mathrm{Ma}^{31}$. b, Photograph facing north showing geographic and stratigraphic relationship between Toroto Tuff, paleobeach, and LOM3.

83 cores, 35 flakes (whole and broken), seven passive elements or potential anvils, seven percussors (whole, broken or potential), three worked cobbles, two split cobbles, and 12 artefacts grouped as indeterminate fragments or pieces lacking diagnostic attributes (Extended Data Table 1a).

Cores are made predominantly from heavy and large-sized cobbles or blocks of lava (mean of the cores: $167 \times 147.8 \times 108.8 \mathrm{~mm}, 3.1 \mathrm{~kg}$;
Extended Data Table 2). Basalts (34.90\%) and phonolites (34.23\%) are the dominant raw materials represented, followed by trachy-phonolite (23.49\%; Extended Data Table 1b), all of which were available in local paleo-channels. Initial survey of a conglomerate source less than $100 \mathrm{~m}$ from the site shows that cobbles and blocks of all sizes were available locally, from which the largest were consistently selected. Most cores were flaked from one striking platform onto one single surface, resulting in several superposed and contiguous unidirectional removals (unifacial partial exploitation), sometimes along a longer part of the perimeter. A few specimens show unifacial partial exploitation by multidirectional removals, while others show bifacial flaking. Significant knapping accidents occurred during flaking, with numerous hinge and step flake terminations visible on cores (Fig. 4a), though more invasive and feather terminating flakes were also often successfully removed. In some cases, cores display a series of shorter $(<1 \mathrm{~cm})$ contiguous small scars along a more limited portion of the platform edge, although it is not yet clear whether this results from the knapping techniques employed, or reflects the utilization of some artefacts in heavy-duty tasks.

To reconstruct more accurately the techniques and reduction strategies used to produce the LOM3 artefacts, an experimental program was undertaken to replicate the lithics found at the site from the same raw materials available locally at LOM3. Together with the technological analysis of the archaeological material, these replication experiments suggest that the LOM3 knappers were using techniques including passive hammer ${ }^{34,35}$ and/or bipolar ${ }^{34}$ (Extended Data Fig. 6) that have to-date rarely been identified in the Oldowan ${ }^{21,22,36,37}$. The average size and weight of the LOM3 cores (Extended Data Table 2) renders direct freehand percussion an arduous undertaking; however, it cannot be ruled out for some of the smaller cores.

The technological features of flakes and flake fragments are clear, unequivocal and seen repeatedly, demonstrating that they were intentionally knapped from the cores. They range from 19 to $205 \mathrm{~mm}$ long (Fig. 5d and Extended Data Table 2) and frequently present cortex on their dorsal surfaces, sometimes on their striking platforms, or both. Three pieces in particular bear localized battered areas on their dorsal surfaces-including the specimen that refits onto the in situ core (Fig. 4a)-showing that blanks were sometimes used for percussive activities before flake removal and that at least some individual blocks were involved in several distinctively different modes of use.

The largest and heaviest (up to $15 \mathrm{~kg}$ ) pieces in the assemblage were made on large blocks of basalt or coarse trachy-phonolite. They have flat natural surfaces that could enable their stabilization for use (Fig. 5a, b and Extended Data Fig. 7a). Comparisons with other described anvils from the Early Stone Age and experiments suggest these can be interpreted as anvils or passive elements ${ }^{38,39}$. Three of these show a similar wear and fracture pattern. The largest piece exhibits along one lateral plane a series of divergent step fractures associated with crushing marks and an additional concentration of impact damage on one horizontal surface (Fig. 5a). The other two pieces have non-invasive step fractures along a greater or lesser portion of their high-angled intersecting surfaces (edges) that are associated with crushing and impact marks (Fig. 5b and Extended Data Fig. 7a). A further two cobbles show heavy battering marks concentrated on a convex area and are interpreted as passive elements. Seven medium-sized cobbles display battering marks and/or impact damage associated with fractured surfaces and are interpreted as hand-held percussors or active elements (Extended Data Figs 7b, c).

\section{Discussion}

LOM3 core and flake techno-morphology does not conform to any observed pattern resulting from accidental natural rock fracture. On the contrary, LOM3 cores and flakes bear all the techno-morphological characteristics of debitage products. Data reported on accidental flakes from chimpanzee nut-cracking sites ${ }^{40}$ falls closer to the flake size spectrum observed at early Oldowan sites than to the size range of LOM3 flakes (Extended Data Table 2). LOM3 knappers were 
a
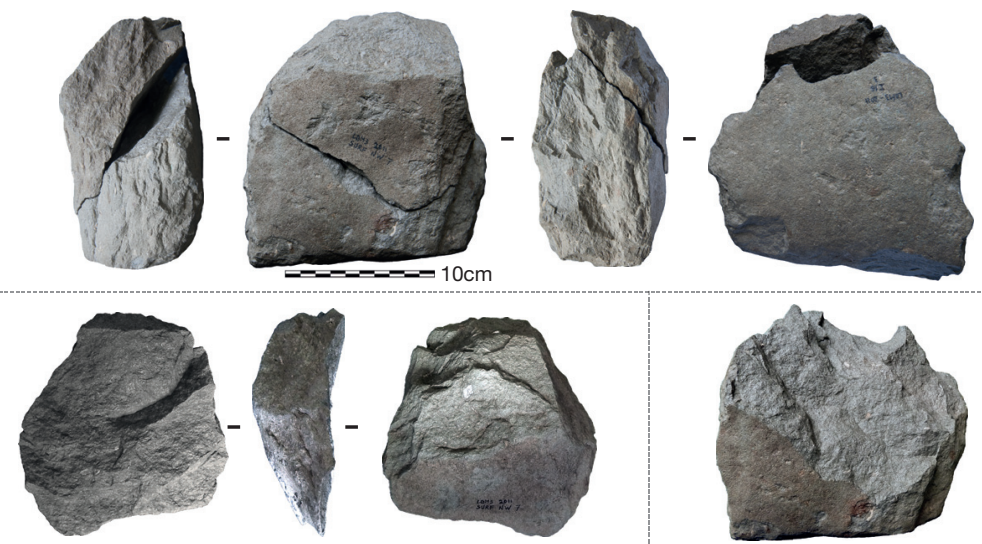

b
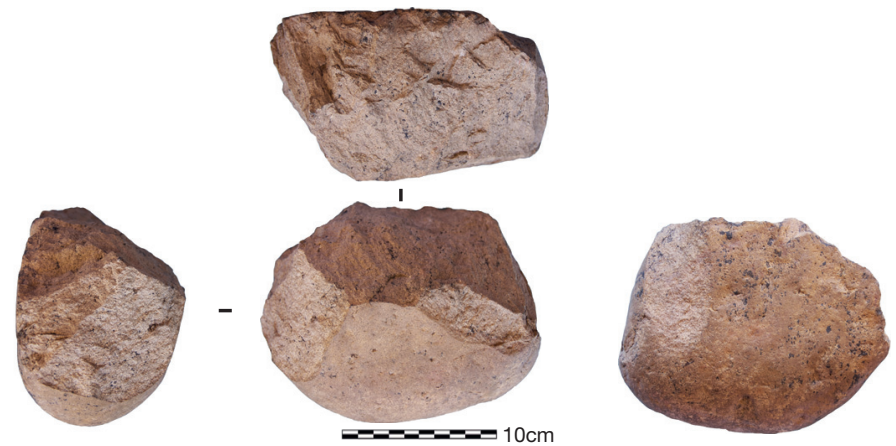

c
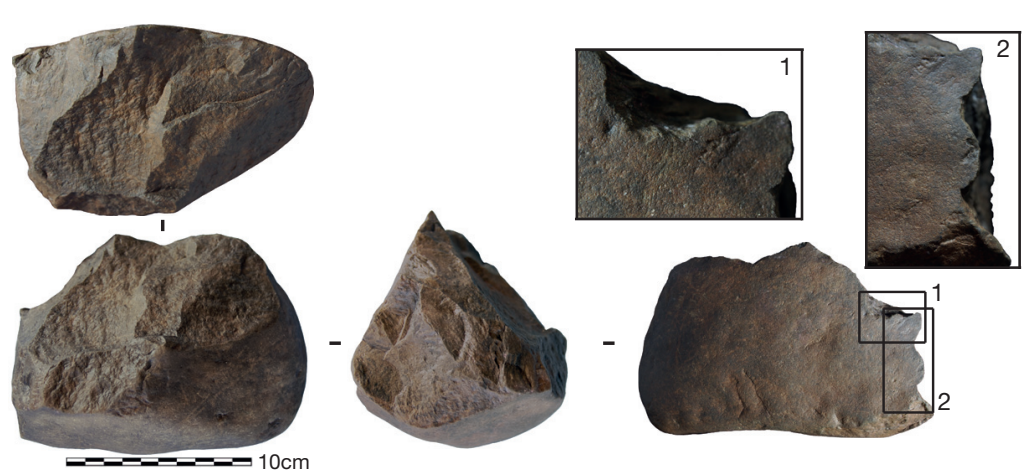

d
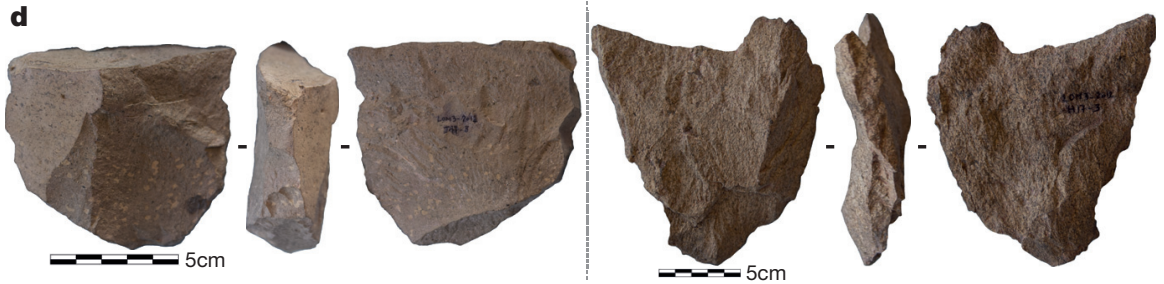

Figure $4 \mid$ Photographs of selected LOM3 artefacts. a, In situ core (LOM3-2011-I16-3, $1.85 \mathrm{~kg}$ ) and refitting surface flake (LOM3-2011 surf NW7, $650 \mathrm{~g}$ ). Unifacial core, passive hammer and bipolar technique. Both the core and the flake display a series of dispersed percussion marks on cortex showing that percussive activities occurred before the removal of the flake, potentially indicating the block was used for different purposes. b, In situ unifacial core (LOM3-2012H18-1, 3.45 kg), bipolar technique. See Extended Data Fig. $6 \mathrm{~b}$ for more details. c, Unifacial core (LOM3-2012 surf 71, 1.84 kg), passive hammer technique. d, Flakes (LOM3-2012-J17-3 and LOM3-2012-H17-3) showing scars of previous removals on the dorsal face. See Supplementary Information part $\mathrm{F}$ for $3 \mathrm{D}$ scans of lithic artefacts. able to deliver sufficient intentional force to repeatedly detach series of adjacent and superposed unidirectional flakes, sometimes invasive, and then to continue knapping either by laterally rotating the cores or by flipping them over for bifacial exploitation. However, though multiple flakes were successfully detached, the majority of flake scars terminate as hinge and step fractures. The precision of the percussive motion was also occasionally poorly controlled, as shown by repeated impact marks on core platforms caused by failed blows applied too far from the striking platform edge to induce fracture. LOM3 lithics (cores and flakes) are significantly larger in length, width, and thickness than those from OGS7, EG10 and EG12 at Gona, A.L. 894 at Hadar, and Omo 57 and Omo 123 in Ethiopia; Lokalalei 2C from West Turkana, Kenya; and DK and FLK Zinj from Olduvai Gorge in Tanzania (Extended Data Table 2). Furthermore, the LOM3 anvils and percussors are larger and heavier than those chosen for nut-cracking by wild chimpanzees in Bossou ${ }^{41}$ (southeastern Guinea; Extended Data Table 3). The dimensions and the percussive-related features visible on the artefacts suggest the LOM3 hominins were combining core reduction and battering activities and may have used artefacts variously: as anvils, cores to produce flakes, and/or as pounding tools. The use of individual objects for several distinctive tasks reflects a degree of technological diversity both much older than previously acknowledged and different from the generally unipurpose stone tools used by primates ${ }^{24,25}$. The arm and hand motions entailed in the two main modes of knapping suggested for the LOM3 assemblage, passive hammer and bipolar, are arguably more similar to those involved in the hammer-on-anvil technique chimpanzees and other primates use when engaged in nut cracking ${ }^{42-44}$ than to the direct freehand percussion evident in Oldowan assemblages. The likely prevalence of these two knapping techniques demonstrates 

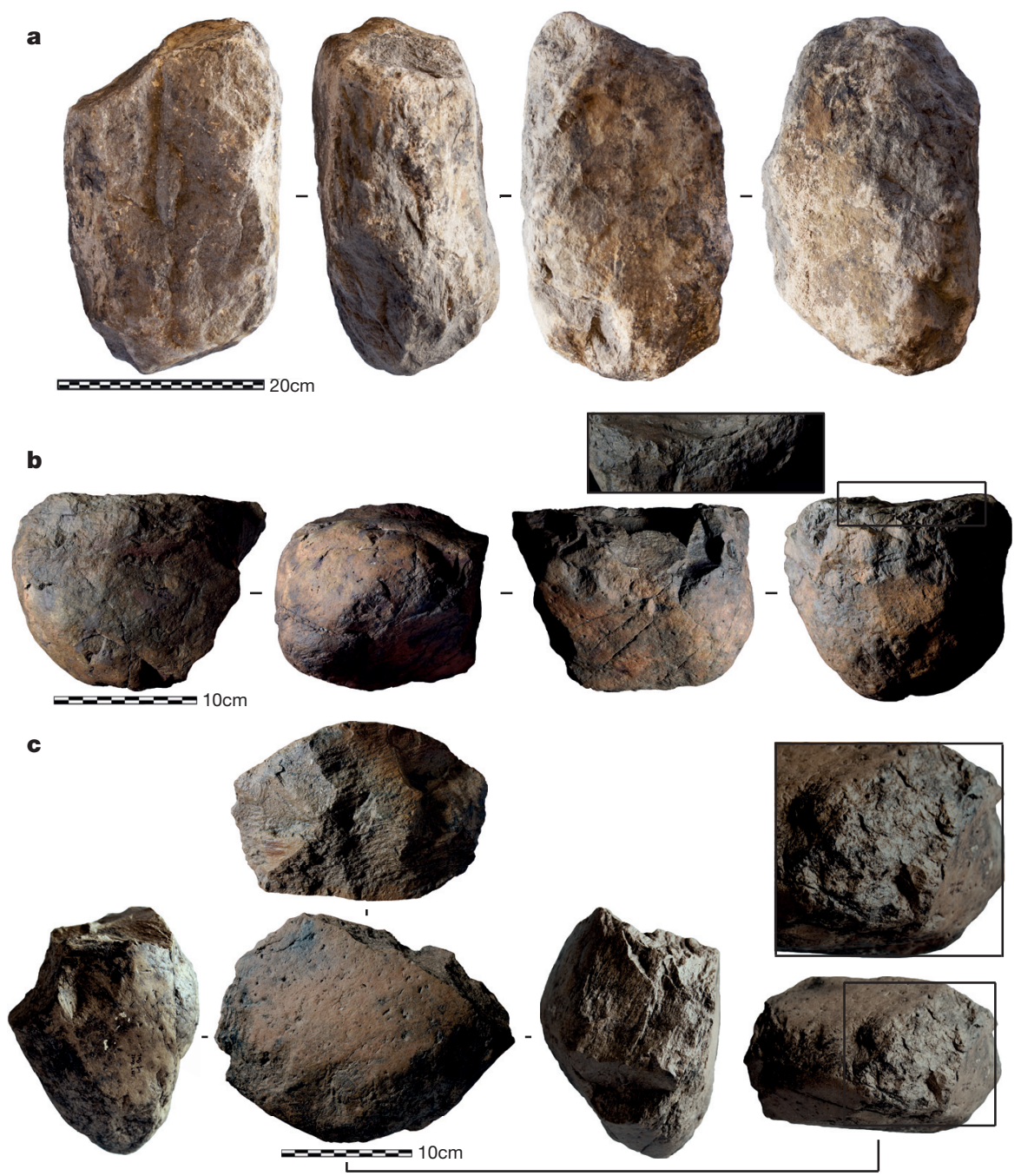

Figure 5 | Photographs of selected LOM3 artefacts. a, In situ passive element/anvil (LOM32012-K18-2, $12 \mathrm{~kg}$ ). b, Passive element/anvil (LOM3-2012 surf 60, 4.9 kg). Both anvils a and b exhibit similar patterns of macroscopic wear consisting of superposed step fracturing in association with crushing and impacts marks. On a, damage is localized on a single lateral face, with battering marks present on one horizontal plane. On $\mathbf{b}$, damage is distributed along a greater portion of the perimeter, but in this case no percussive marks are identifiable on the horizontal plane. In both cases, the intensity of the observed wear signature indicates a use in heavy-duty activities. c, Unifacial core (LOM3-2012 surf 90, 4.74 kg), bipolar technique and semi-peripheral exploitation. Inset shows crushing marks on the proximal surface of the cobble related to battering activities before or after the knapping of the core. See Supplementary Information part F for threedimensional scans of lithic artefacts. the central role that they might have played at the dawn of technology, as previously suggested ${ }^{21,22,36,37}$.

LOM3 predates the oldest fossil specimens attributed to Homo in West Turkana at $2.34 \pm 0.04 \mathrm{Ma}^{7}$ by almost a million years; the only hominin species known to have been living in the West Turkana region at the time is $K$. platyops ${ }^{27}$, while Australopithecus afarensis is found in the Lower Awash Valley at 3.39 Ma in association with cutmarked bones from Dikika ${ }^{20}$. The LOM3 artefacts indicate that their makers' hand motor control must have been substantial and thus that reorganization and/or expansion of several regions of the cerebral cortex (for example, somatosensory, visual, premotor and motor cortex), cerebellum, and of the spinal tract could have occurred before 3.3 Ma. The functional morphology of the upper limb of Pliocene hominins (especially A. afarensis, the only species for which contemporaneous fossil hand and wrist elements are known), particularly in terms of adaptations for stone tool making, must be investigated further if this important milestone in human evolution is to be understood more fully (Supplementary Information, part A).

Critical questions relating to how the LOM3 assemblage compares with the previously known earliest hominin stone tool techno-complex, the Oldowan, remain. They are difficult to address because the term Oldowan has been defined differently since it was first employed in 1934 (refs 16, 45-47). The simplest defining characteristics of the Oldowan are that its knappers show the earliest evidence of a basic understanding of the conchoidal fracture mechanics of stone and were able to effectively strike flakes from cores, more often than not knapping using 'grammars of action'48 and predominantly using the free-hand knapping technique ${ }^{11,17}$. The LOM3 knappers' understanding of stone fracture mechanics and grammars of action is clearly less developed than that reflected in early Oldowan assemblages and neither were they predominantly using free-hand technique. The LOM3 assemblage could represent a technological stage between a hypothetical poundingoriented stone tool use by an earlier hominin and the flaking-oriented knapping behaviour of later, Oldowan toolmakers. The term 'PreOldowan' has been suggested for modified stones if ever found in deposits older than 2.6 Ma, especially if they are different in terms of knapping skill from the Oldowan sensu stricto ${ }^{49}$ (this is not to be confused with previous uses of the same term by some authors to describe the early Oldowan period between $2.6-2 \mathrm{Ma}^{50}$ ). The LOM3 assemblage may therefore concord with such a premise. We assert, however, that the technological and morphological differences between the LOM3 and early Oldowan assemblages are significant enough that amalgamating them would mask important behavioural and cognitive changes occurring among hominins over a nearly 2-million-year timespan. A separate name for the LOM3 assemblage is therefore warranted. Given the paradigmatic shift that LOM3 portends for models that aim to converge environmental change, hominin evolution and technological origins, the name Lomekwian is proposed. In any scenario, the LOM3 stone tools mark a new beginning to the known archaeological record, now shown to be more than 700,000 years older than previously thought. Note added in proof: The recently described LD 350-1 partial mandible from Ethiopia now provides the earliest evidence of the genus Homo at $2.8 \mathrm{Ma}$ (Villmoare, B. et al. Early Homo at 2.8 Ma from LediGeraru, Afar, Ethiopia. Science, 347, 1352-1355). The LOM3 artefacts 
still predate the known origins of Homo by half a million years and the question of what hominin species made them remains.

Online Content Methods, along with any additional Extended Data display items and Source Data, are available in the online version of the paper; references unique to these sections appear only in the online paper.

\section{Received 1 November 2012; accepted 13 April 2015.}

1. Leakey, L. S. B., Tobias, P. V. \& Napier, J. R. A new species of the genus Homo from Olduvai Gorge. Nature 202, 7-9 (1964)

2. Harris, J. W. K. Cultural beginnings: Plio-Pleistocene archaeological occurrences from the Afar Rift, Ethiopia. Afr. Archaeol. Rev. 1, 3-31 (1983).

3. Quinn, R. L. et al. Pedogenic carbonate stable isotopic evidence for wooded habita preference of early Pleistocene tool makers in the Turkana Basin. J. Hum. Evol. 65 65-78 (2013)

4. Bobe, R. \& Behrensmeyer, A. K. The expansion of grassland ecosystems in Africa in relation to mammalian evolution and the origin of the genus Homo. Palaeogeogr. Palaeoclimatol. Palaeoecol. 207, 399-420 (2004).

5. Roche, H. \& Tiercelin, J.-J. Découverte d'une industrie lithique ancienne in situ dans la formation d'Hadar, Afar central, Ethiopie. C. R. Acad. Sci. Paris D 284, 1871-1874 (1977).

6. Semaw, S. et al. 2.5-million-year-old stone tools from Gona, Ethiopia. Nature 385, 333-336 (1997).

7. Prat, S. et al. First occurrence of early Homo in the Nachukui Formation (West Turkana, Kenya) at 2.3-2.4 Myr. J. Hum. Evol. 49, 230-240 (2005)

8. Kimbel, W. H. et al. Late Pliocene Homo and Oldowan tools from the Hadar formation (Kada Hadar member), Ethiopia. J. Hum. Evol. 31, 549-561 (1996).

9. Antón, S. C., Potts, R. \& Aiello, L. C. Evolution of early Homo: An integrated biological perspective. Science 345, 1236828 (2014)

10. Panger, M., Brooks, A. S., Richmond, B. G. \& Wood, B. Older than the Oldowan? Rethinking the emergence of hominin tool use. Evol. Anthropol. 11,235-245 (2002).

11. Roche, H., Blumenschine, R. J. \& Shea, J. J. in The First Humans - Origin and Early Evolution of the Genus Homo (eds Grine, F. E., Fleagle, J. G. \& Leakey, R. E.) 135-147 (Springer, 2009).

12. Semaw, S. et al. 2.6-Million-year-old stone tools and associated bones from OGS-6 and OGS-7, Gona, Afar, Ethiopia. J. Hum. Evol. 45, 169-177 (2003).

13. Campisano, C. J. Geological summary of the Busidima Formation (Plio-Pleistocene) at the Hadar paleoanthropological site, Afar Depression, Ethiopia. J. Hum. Evol. 62 338-352 (2012).

14. de la Torre, I. Omo revisited: evaluating the technological skills of Pliocene hominids. Curr. Anthropol. 45, 439-465 (2004).

15. Roche, H. et al. Early hominid stone tool production and technical skill $2.34 \mathrm{Myr}$ ago in West Turkana, Kenya. Nature 399, 57-60 (1999).

16. Delagnes, A. \& Roche, H. Late Pliocene hominid knapping skills: the case of Lokalalei 2C, West Turkana, Kenya. J. Hum. Evol. 48, 435-472 (2005)

17. Stout, D., Semaw, S., Rogers, M. J. \& Cauche, D. Technological variation in the earliest Oldowan from Gona, Afar, Ethiopia. J. Hum. Evol. 58, 474-491 (2010)

18. Harmand, S. in Interdisciplinary Approaches to the Oldowan (eds Hovers, E. \& Braun, D. R) 85-97 (Springer, 2009).

19. Goldman-Neuman, T. \& Hovers, E. Raw material selectivity in Late Pliocene Oldowan sites in the Makaamitalu Basin, Hadar, Ethiopia. J. Hum. Evol. 62, 353-366 (2012).

20. McPherron, S. P. etal. Evidence for stone-tool-assisted consumption of animal tissues before 3.39 million years ago at Dikika, Ethiopia. Nature 466, 857-860 (2010)

21. Mora, R. \& de la Torre, I. Percussion tools in Olduvai Beds I and II (Tanzania): implications for early human activities. J. Anthropol. Archaeol. 24, 179-192 (2005).

22. Diez-Martín, F., Sánchez Yustos, P., Domínguez-Rodrigo, M., Mabulla, A. Z.P. \& Barba, R. Were Olduvai hominins making butchering or battering tools? Analysis of a recently excavated lithic assemblage from BK (Bed II, Olduvai Gorge, Tanzania). J. Anthropol. Archaeol. 28, 274-289 (2009).

23. Blumenschine, R. J. \& Selvaggio, M. M. Percussion marks on bone surfaces as a new diagnostic of hominid behaviour. Nature 333, 763-765 (1988)

24. Marchant, L. \& McGrew, W. in Stone Knapping: the Necessary Conditions for a Uniquely Hominin Behavior (eds Roux, V. \& Brill, B.) 341-350 (Cambridge McDonald Institute, 2005)

25. Carvalho, S., Cunha, E., Sousa, C. \& Matsuzawa, T. Chaînes opératoires and resource-exploitation strategies in chimpanzee (Pan troglodytes) nut cracking. J. Hum. Evol. 55, 148-163 (2008).

26. Harris, J. M., Brown, F. H. \& Leakey, M. G. Stratigraphy and paleontology of Pliocene and Pleistocene localities west of Lake Turkana, Kenya. Contr. Sci. Nat. Mus. Los Angeles 399, 1-128 (1988).

27. Leakey, M. G. et al. New hominin genus from eastern Africa shows diverse middle Pliocene lineages. Nature 410, 433-440 (2001).

28. Wood, B. \& Leakey, M. G. The Omo-Turkana Basin fossil hominins and their contribution to our understanding of human evolution in Africa. Evol. Anthropol. 20, 264-292 (2011).

29. McDougall, I. \& Brown, F. H. Geochronology of the pre-KBS Tuff sequence, Turkana Basin. J. Geol. Soc. Lond. 165, 549-562 (2008).

30. McDougall, l. et al. New single crystal ${ }^{40} \mathrm{Ar} /{ }^{39} \mathrm{Ar}$ ages improve time scale for deposition of the Omo Group, Omo-Turkana Basin, East Africa. J. Geol. Soc. Lond. 169, 213-226 (2012).

31. Lourens, L. J., Hilgen, F. J., Laskar, J., Shackleton, N. J. \& Wilson, D. The Neogene Period. A Geological Time Scale 2004 (eds Gradstein, F. M., Ogg, J. G. \& Smith, A. G.) 409-440 (Cambridge University Press, 2004).
32. Cerling, T. E. et al. Woody cover and hominin environments in the past 6 million years. Nature 476, 51-56 (2011).

33. Quade, J. et al. Paleoenvironments of the earliest stone toolmakers, Gona, Ethiopia Geol. Soc. Am. Bull. 116, 1529-1544 (2004)

34. Crabtree, D. E. An introduction to flintworking. Part 1. An introduction to the technology of stone tools. Occasional Papers of the Idaho State University Museum, 28, (Idaho State Univ. Museum, 1972).

35. Mourre, V., Jarry, M., Colonge, D. \& Lelouvier, L.-A. Le débitage sur enclume aux Bosses (Lamagdalaine, Lot, France). Paleo (special issue) 49-62 (2010).

36. Diez-Martin, F. et al. New insights into hominin lithic activities at FLK North Bed I, Olduvai Gorge, Tanzania. Quat. Res. 74, 376-387 (2010).

37. de la Torre, I. \& Mora, R. A technological analysis of non-flaked stone tools in Olduvai Beds I \& II. Stressing the relevance of percussion activities in the African Lower Pleistocene. Paleo (special issue) 13-34 (2010).

38. Alimen, M. H. Enclumes (percuteurs dormants) associées à l'Acheuléen supérieur de l'Ougartien (Oued Farès, Sahara occidental). Bull. Soc. Préhist. Fr. 60, 43-47 (1963).

39. Leakey, M. D. Olduvai Gorge, Vol. 3. Excavations in Beds I and I/ 1960-1963 (Cambridge Univ. Press, 1971).

40. Mercader, J. et al. 4,300-year-old chimpanzee sites and the origins of percussive stone technology. Proc. Natl Acad. Sci. USA 104, 3043-3048 (2007)

41. Sakura, O. \& Matsuzawa, T. Flexibility of wild chimpanzee nut-cracking behavior using stone hammers and anvils: an experimental analysis. Ethology 87, 237-248 (1991).

42. Haslam, M. et al. Primate archaeology. Nature 460, 339-344 (2009).

43. Visalberghi, E., Haslam, M., Spagnoletti, N. \& Fragaszy, D. Use of stone hammer tools and anvils by bearded capuchin monkeys over time and space: construction of an archeological record of tool use. J. Archaeol. Sci. 40, 3222-3232 (2013).

44. Matsuzawa, T. in Great Ape Societies (eds McGrew, W. et al.) 196-209 (Cambridge Univ. Press, 1996).

45. Leakey, L. S. B. in Essays Presented to C. G. Seligman (eds Evans-Pritchard, E. E., Firth, R. Malinowski, B. \& Schapera, I.) 143-146 (K. Paul, Trench, Trubner \& Co, 1934).

46. de la Torre, I. The origins of stone tool technology in Africa: a historical perspective. Phil. Trans. R. Soc. B. 366, 1028-1037 (2011).

47. Shea, J. Lithic modes A-l: a new framework for describing global-scale variation in stone tool technology illustrated with evidence from the East Mediterranean Levant. J. Archaeol. Method Theory 20, 151-186 (2013).

48. Hovers, E. in Origins of Human Innovation and Creativity (ed. Elias, S.) 51-68 (Elsevier, 2012)

49. Toth, N., Schick, K. \& Semaw, S. in The Oldowan: Case Studies into the Earliest Stone Age (eds Toth, N. \& Schick, K. D.) 155-222 (Stone Age Institute Press, 2006)

50. Piperno, M. in Hominidae: Proc. 2nd Intl Congr. Human Paleontol. 1987 189-195 (Jaca Books, 1989).

Supplementary Information is available in the online version of the paper.

Acknowledgements We thank the office of the President of Kenya, the Ministry of Education, Science and Technology, the National Council for Science and Technology (NCST/RCD/12B/012/25) and the National Museums of Kenya for permission to conduct research. Funding was provided by the French Ministry of Foreign Affairs (N ${ }^{\circ}$ 681/DGM/ATT/RECH, N ${ }^{\circ}$ 986/DGM/DPR/PRG), the French National Research Agency (ANR-12-CULT-0006), the Fondation Fyssen, the National Geographic Society (Expeditions Council \#EC0569-12), the Rutgers University Research Council and Center for Human Evolutionary Studies, and INTM Indigo Group France. We thank the Turkana Basin Institute and Total Kenya Limited for logistical support and the GeoEye Foundation for satellite imagery; the Turkana communities from Nariokotome, Kokiselei and Katiko for field assistance, and the 2011-12 WTAP team, S. Kahinju, P. Egolan, L. P. Martin, D. Massika, B. K. Mulwa S. M. Musyoka, A. Mutisiya, J. Mwambua, F. M. Wambua, M. Terrade, A. Weiss, R. Benitez, S. Feibel. M. Leakey and F. Spoor supplied information on hominin fossils, and I. de la Torre and E. Hovers provided lithic assemblage data. We are very grateful to A. Brooks, I. de la Torre, J. Shea, R. Klein and M. Leakey for comments on earlier drafts. We also thank the Zoller \& Fröhlich GmbH company, Ch. Fröhlich and M. Reinköster, Autodesk and Faro (T. O'Mahoney, K. Almeida Warren and T. Gichunge) for technical support with scanning and J.P. Chirey for photographic assistance.

Author Contributions S.H. and J.E.L. directed field research and co-wrote the overal paper. C.S.F., C.J.L., A.L. and X.B. recorded sedimentological and stratigraphic data, conducted geological mapping, and wrote sections of the paper. C.S.F. interpreted tephra data. C.J.L. interpreted paleomagnetic data. S.P., J.-Ph.B., S.L., C.K. and L.L. conducted paleontological survey. S.P., J.-Ph.B. and L.L. analysed and interpreted fossil material. L.L. directed scanning of artefacts. S.P. laser scanned artefacts and excavation surfaces, and wrote sections of the paper. R.L.Q. interpreted isotopic data and wrote sections of the paper. C.S.F., C.J.L., R.L.Q., R.A.M., J.D.W. and D.V.K. analysed geological samples. G.D. developed protocols for tool replication experiments and wrote sections of the paper. S.H., H.R., N.T., M.B., S.C., S.L. and C.K. conducted archaeological survey and excavation. S.H., H.R., A.A., N.T. and M.B. analysed and interpreted lithic material and wrote sections of the paper. M.B. performed lithic replication experiments. S.C. provided spatial data. S.L. discovered the LOM3 site.

Author Information Reprints and permissions information is available at www.nature.com/reprints. The authors declare no competing financial interests. Readers are welcome to comment on the online version of the paper. Correspondence and requests for materials should be addressed to S.H. (sonia.harmand@stonybrook.edu) or J.L. (jason.lewis@stonybrook.edu). 


\section{METHODS}

Paleomagnetic analyses. All samples from the Lomekwi outcrops were collected from fresh surfaces uncovered by digging into the exposures for at least $20 \mathrm{~cm}$. Before each hand-cut block was extracted, in situ azimuths and dips were recorded on a sample using a compass-inclinometer. Samples were taken typically at nominal $1 \mathrm{~m}$ vertical stratigraphic intervals, or as the distribution of finegrained strata allowed. Two sections were sampled, separated from each other by about $1 \mathrm{~km}$ north to south across the landscape (Extended Data Fig. 2). Overlapping Sections 1 and 2 (Fig. 3a) are each composed of a coarsening upward succession of mudstones abruptly overlain by gravels and followed by a thick unit of gravels and mudstones, which likely records a lacustrine regression and the emplacement of a prograding alluvial fan. Inset in Fig. 3a shows stratigraphic thickness of composite section plotted against key chronostratigraphic levels $(\alpha$-Tulu Bor $(\alpha$-TB), $3.44 \pm 0.02$; Toroto Tuff, $3.31 \pm 0.02 \mathrm{Ma}$; C2An. $3 \mathrm{n} / .2 \mathrm{r}$ boundary, $3.33 \mathrm{Ma}^{31}$; Lokalalei Tuff, $\left.2.53 \pm 0.02\right)$.

At Section 1 (Fig. 3a), sampling began at about $10 \mathrm{~m}$ below the lowermost stratigraphic level of the $\alpha$-Tulu Bor Tuff. Sampling continued upwardly from the $\alpha$-Tulu Bor Tuff for another $35 \mathrm{~m}$, for a total of $\sim 45 \mathrm{~m}$ sampled. At Section 2 (Fig. 3a), sampling commenced at the Tororo Tuff. Sampling started upwardly from the Toroto Tuff for about $10 \mathrm{~m}$ to the level of the archaeological horizon at LOM3, and then proceeded upwardly for another $35 \mathrm{~m}$ for a total sampled stratigraphic thickness of about $45 \mathrm{~m}$ at Section 2.

For laboratory analyses, samples were cut into standard cube-shape specimens $(\sim 10 \mathrm{cc})$ using a lapidary saw and sandpaper. All magnetic remanence measurements were made with a 2 G DCSQUID rock magnetometer in the shielded room at the Paleomagnetics Laboratory of Lamont-Doherty Earth Observatory (Columbia University). The natural remanent magnetization (NRM) of a specimen was subjected to progressive Thermal Demagnetization (TD) using 14 to 17 steps at 100,50 and $25^{\circ} \mathrm{C}$ increments in the temperature range of $100-700^{\circ} \mathrm{C}$. Data from consecutive high-temperature steps were used for principal component analysis $\left(\mathrm{PCA}^{51}\right)$ to fit least-square lines tied to the origin for the final demagnetization trajectories defining the characteristic remanent magnetization (ChRM) as revealed on orthogonal projection plots (Extended Data Fig. 3a) Magnetic susceptibility values were determined with a Bartington MS2B instrument for each specimen initially and after each TD heating step to monitor any laboratory-induced magnetochemical alteration. The virtual geomagnetic pole (VGP) latitude corresponding to the ChRM direction was used to determine the magnetostratigraphic polarity sequence. In Fig. 3a, filled black circles joined by lines (isolated red squares) denote accepted (rejected) data with maximum angular deviation $(\mathrm{MAD})$ values $<15^{\circ}\left(>15^{\circ}\right)$ from principal component analyses. Characteristic remanent magnetizations were isolated after the removal of a pervasive normal polarity overprint unblocked by a TD range of $600-670{ }^{\circ} \mathrm{C}$ for the coarse alluvial fan strata (essentially all of Section 2 above the Toroto Tuff) and a TD range of $400-550^{\circ} \mathrm{C}$ for the finer strata (for example, mudstones from the lower part of Section 1).

Pedogenic carbonate stable carbon isotopic analysis. Sedimentological field analysis identified eleven paleosols with discernible preserved $B_{K}$ horizons. Ten paleosols were sampled from Section 2011-1, and one from 2011-2 (Extended Data Fig. 2). Carbonate nodules were extracted from paleosols $>30 \mathrm{~cm}$ below the contact with overlying stratum with vertic features within peds showing slickensided surfaces. Twenty-four cross-sectioned nodules (five from one paleosol at LOM3, 2011-2) were sampled with a $0.5 \mathrm{~mm}$ carbide drill bit (Foredom Series) and loaded into v-vials for single acid baths (multi-prep device). Forty-seven isotopic analyses were conducted on a Micromass Optima mass spectrometer in the Department of Earth and Planetary Sciences at Rutgers University. Samples were reacted at $90{ }^{\circ} \mathrm{C}$ in $100 \%$ phosphoric acid for $13 \mathrm{~min} . \delta^{13} \mathrm{C}_{\mathrm{VPDB}}$ values are reported in the standard per mil (\%o) notation: $=\left(R_{\text {sample }} / R_{\text {standard }}-1\right) \times 1000$, relative to Vienna-Pee Dee Belemnite through analysis of laboratory standard NBS-19 (Extended Data Fig. 4). Analytical error is $\pm 0.05 \%$. Using methods of ref. 32 , we subtracted $14 \%$ from the $\delta^{13} \mathrm{C}_{\mathrm{VPDB}}$ values of pedogenic carbonate to convert to the isotopic equivalent of organic carbon $\left(\delta^{13} \mathrm{C}_{o m}\right)$ and used the equation: $f_{\mathrm{wc}}=\left\{\sin \left[-1.06688-0.08538\left(\delta^{13} \mathrm{C}_{o m}\right)\right]\right\}^{2}$ to generate estimates of fraction woody canopy cover for classification into UNESCO categories of African vegetation. Categories were taken from White ${ }^{52}$ and have the following $\delta^{13} \mathrm{C}_{\mathrm{VPDB}}$ value ranges of pedogenic carbonate ${ }^{32}$ : (1) forest: continuous stand of trees at least $10-\mathrm{m}$ tall with interlocking crowns with greater than $80 \%$ woody $\operatorname{cover}\left(\delta^{13} \mathrm{C}_{\mathrm{VPDB}}:>-11.5\right.$
$\%$ ), (2) woodland/bushland/thicket/shrubland: woodland is an open stand of trees at least $8 \mathrm{~m}$ tall with woody cover $>40 \%$ and a field layer dominated by grasses; bushland is an open stand of bushes between $3 \mathrm{~m}$ and $8 \mathrm{~m}$ tall with woody cover $>40 \%$; thicket is a closed stand of bushes and climbers between $3 \mathrm{~m}$ and $8 \mathrm{~m}$ tall; shrubland is an open or closed stand of shrubs up to $2 \mathrm{~m}$ tall $\left(\delta^{13} \mathrm{C}_{\mathrm{VPDB}}:-11.5\right.$ to $-6.5 \%$ ), (3) wooded grassland: land covered with grassland and has $10-40 \%$ tree or shrub cover $\left(\delta^{13} \mathrm{C}_{\mathrm{VPDB}}:-6.5\right.$ to $-2.3 \%$ ) and (4) grassland: land covered with herbaceous plants with less than $10 \%$ tree and shrub cover $\left(\delta^{13} \mathrm{C}_{\mathrm{VPDB}}:<-2.3 \%\right.$ ). We also calculated percent $\mathrm{C}_{4}$ biomass using a simple linear mixing model assuming $-12 \%$ and $-26 \%$ as the $\mathrm{C}_{4}$ and $\mathrm{C}_{3}$ end members, respectively ${ }^{53}$

Site scanning. To document the uncovering of the in situ artefacts and fossils during the excavation, we took frequent 3D scans of the surface of individual squares with the OptiNum RE handheld device (manufactured by Noomeo Products, France) with a maximum spatial resolution of $300 \mu \mathrm{m}$. Additionally, thanks to a collaboration between Zoller \& Fröhlich GmbH and Autodesk, we had access to a recently developed high-resolution industrial 3D scanner operated by M. Reinköster. This scanner was able to scan the entire site, registering 500,000 $3 \mathrm{D}$ points each second, with a spatial resolution of $<3,000 \mu \mathrm{m}$, and recording for several minutes continuously. After the laser scan a $3 \mathrm{D}$ photo was taken which can be draped around the scan. The site was scanned in this manner after each day of excavation. In this way, a high-resolution 3D digital model can be created for the entire site, and individual squares, showing the evolution of the excavation and the original context and gradual uncovering of the in situ artefacts and fossils. Stone tool scanning. A representative sample of the LOM3 artefacts were scanned at the National Museums of Kenya and the Turkana Basin Institute facility in Turkwel, using a LMI Technologies R3 Advance portable structured light scanner (LMI Technologies, Vancouver, Canada), calibrated to the size of the objects in question, with the calibration grids being accurate to $50 \mu \mathrm{m}$. For colour texture overlay, a Canon 600D/Rebel T3i SLR digital camera was also calibrated with the scanner and images from this formed the base of the colour texture. The textured files are saved in .obj format and non textured files (for 3D printing or similar purposes) are saved in .stl format. These scans and 3-D digital models are available at (http://africanfossils.org/search).

Sample size. No statistical methods were used to predetermine sample size

51. Kirschvink, J. L. The least-squares line and plane and the analysis of palaeomagnetic data. Geophys. J. Int. 62, 699-718 (1980).

52. White, $F$. The vegetation of Africa, a descriptive memoir to accompany the UNESCO/AETFAT/UNSO vegetation map of Africa. UNESCO. Nat. Resour. Res. 20, $1-356$ (1983).

53. Fox, D. L. \& Koch, P. L. Carbon and oxygen isotopic variability in Neogene paleosol carbonates: constraints on the evolution of the C4-grasslands of the Great Plains, USA. Palaeogeogr. Palaeoclimatol. Palaeoecol. 207, 305-329 (2004).

54. Levin, N. E., Quade, J., Simpson, S. W., Semaw, S. \& Rogers, M. J. Isotopic evidence for Plio-Pleistocene environmental change at Gona, Ethiopia. Earth Planet. Sci. Lett. 219, 93-110 (2004).

55. Levin, N. E. Compilation of East Africa soil carbonate stable isotope data. Integrated Earth Data Applications http://dx.doi.org/10.1594/IEDA/100231 (2013).

56. Cerling, T. E., Bowman, J. R. \& O'Neil, J. R. An isotopic study of a fluvial-lacustrine sequence: the Plio-Pleistocene Koobi Fora sequence, East Africa. Palaeogeogr. Palaeoclimatol. Palaeoecol. 63, 335-356 (1988).

57. Levin, N. E., Brown, F. H., Behrensmeyer, A. K., Bobe, R. \& Cerling, T. E. Paleosol carbonates from the Omo Group: isotopic records of local and regional environmental change in East Africa. Palaeogeogr. Palaeoclimatol. Palaeoecol. 307, 75-89 (2011) CrossRef.

58. Wynn, J. G. Influence of Plio-Pleistocene aridification on human evolution: evidence from paleosols from the Turkana Basin, Kenya. Am. J. Phys. Anthropol. 123, 106-118 (2004)

59. Kingston, J. D. Stable isotopic evidence for hominid paleoenvironments in East Africa. Ph.D. Thesis, Harvard Univ. (1992)

60. Aronson, J. L., Hailemichael, M. \& Savin, S. M. Hominid environments at Hadar from paleosol studies in a framework of Ethiopian climate change. J. Hum. Evol. 55, 532-550 (2008).

61. Wynn, J. G. et al. Geological and palaeontological context of a Pliocene juvenile hominin at Dikika, Ethiopia. Nature 443, 332-336 (2006).

62. Semaw, S., Rogers, M. J. \& Stout, D. In The Cutting Edge: New Approaches to the Archaeology of Human Origins (eds Schick, K. D. \& Toth, N.) 211-246 (Stone Age Institute Press, 2009).

63. Hovers, E. In The Cutting Edge: New Approaches to the Archaeology of Human Origins (eds Schick, K. D. \& Toth, N.) 137-150 (Stone Age Institute Press, 2009).

64. de la Torre, I. \& Mora, R. Technological Strategies in the Lower Pleistocene at Olduvai Beds I \& II. ERAUL 112 (2005). 
a

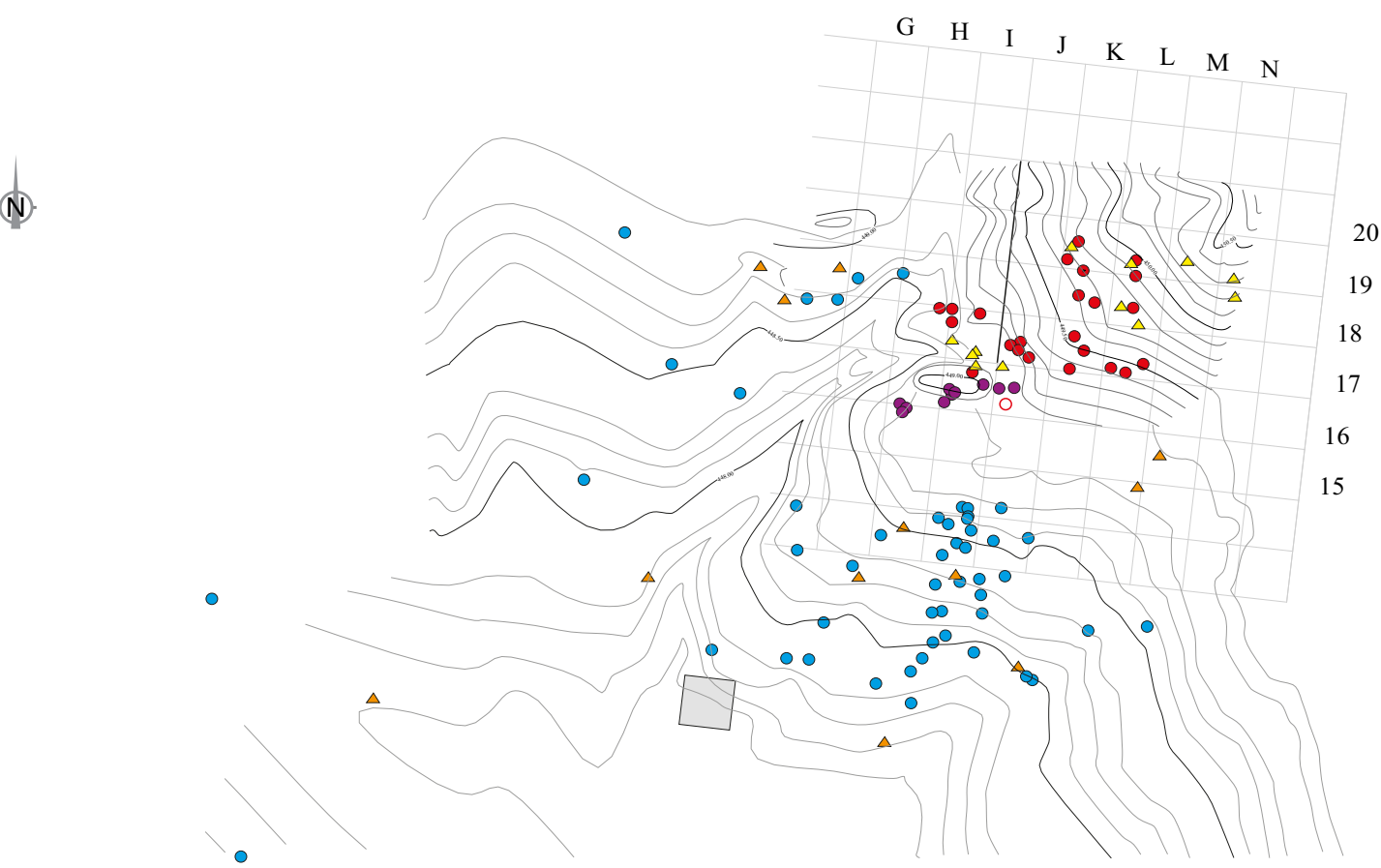

○

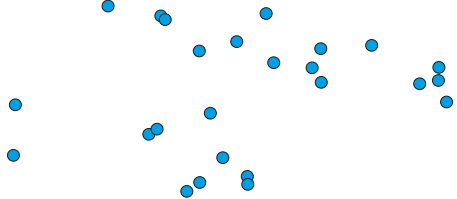

$\circ$

。

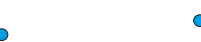

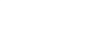
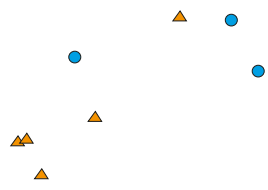

○
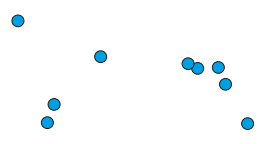


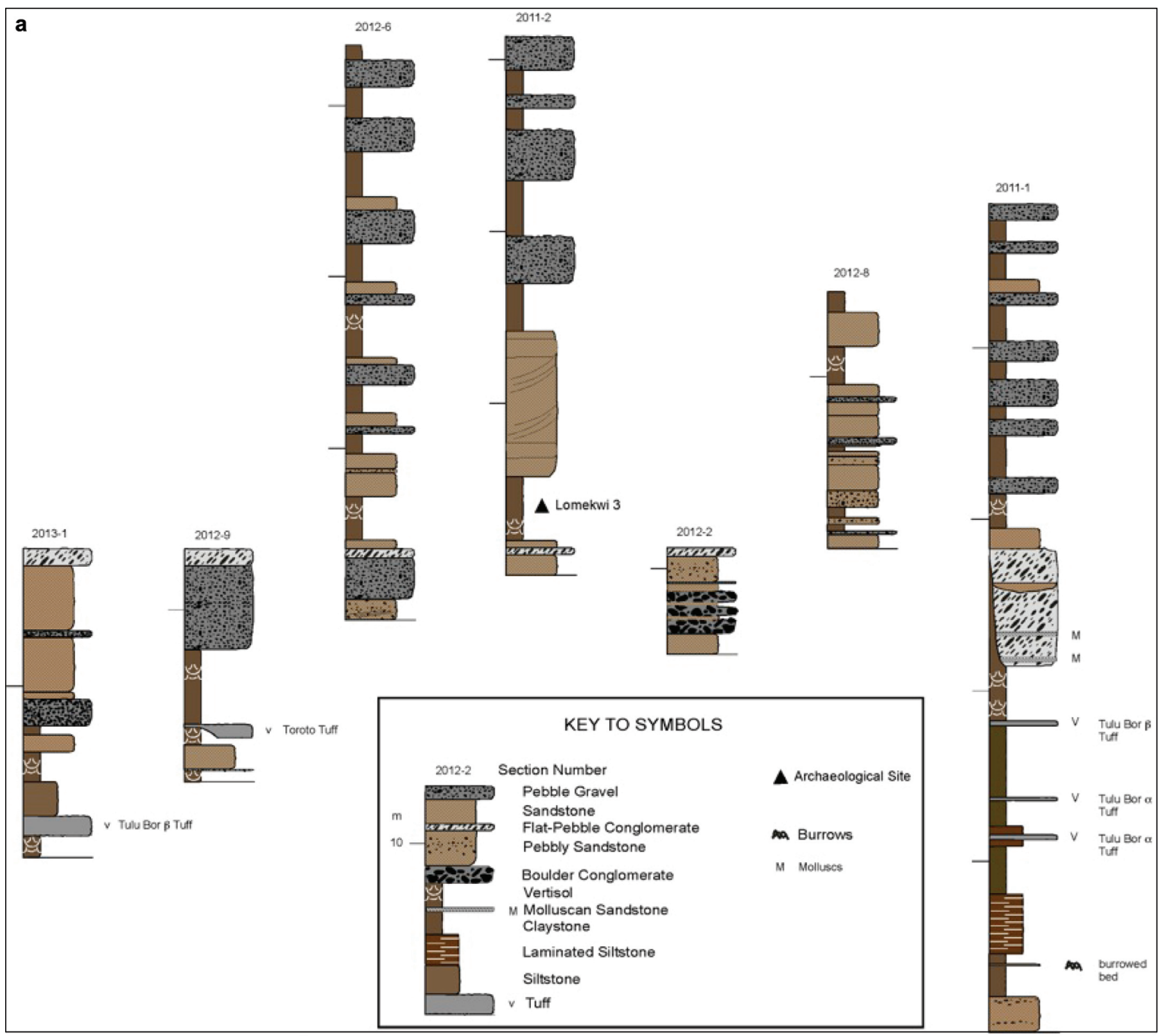

b

\begin{tabular}{lcc}
\hline & N Lat (d mm.mmm) & E Long (dd mm.mmm) \\
\hline base 2011-1 & 352.441 & 3545.201 \\
top 2011-1 & 352.219 & 3545.325 \\
base 2011-2 & 351.806 & 3545.183 \\
top 2011-2 & 351.814 & 3545.292 \\
base 2012-2 & 351.627 & 3545.228 \\
top 2012-2 & 351.662 & 3545.251 \\
base 2012-6 & 351.875 & 3544.932 \\
top 2012-6 & 351.969 & 3544.971 \\
base 2012-8 & 351.679 & 3545.268 \\
top 2012-8 & 351.699 & 3545.282 \\
base 2012-9 & 351.473 & 3545.205 \\
top 2012-9 & 351.512 & 3545.181 \\
base 2013-1 & 351.485 & 3544.973 \\
top 2013-1 & 351.511 & 35.45 .003 \\
\hline
\end{tabular}

Extended Data Figure $2 \mid$ Geology of the LOM3 site. a, Stratigraphic sections around LOM3 (locations in b), showing relationship of site to marker tuffs and lithofacies. Sections aligned relative to top of flat-pebble conglomerate unit. b, GPS coordinates of stratigraphic sections (WGS84 datum). 

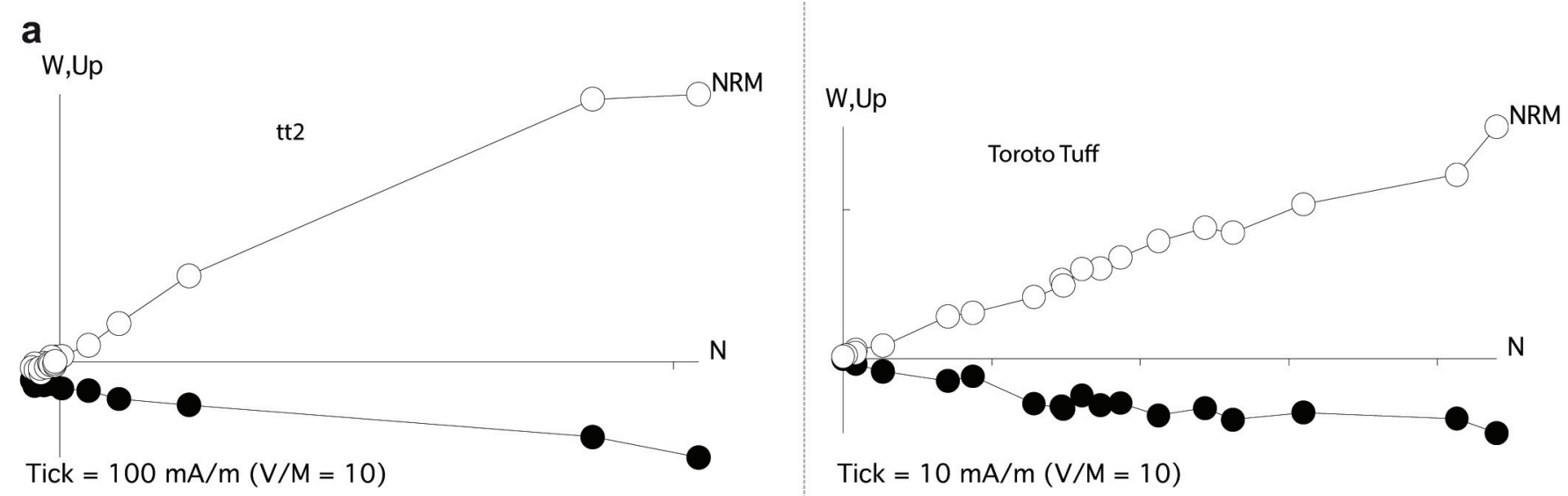

Tick $=10 \mathrm{~mA} / \mathrm{m}(\mathrm{V} / \mathrm{M}=10)$
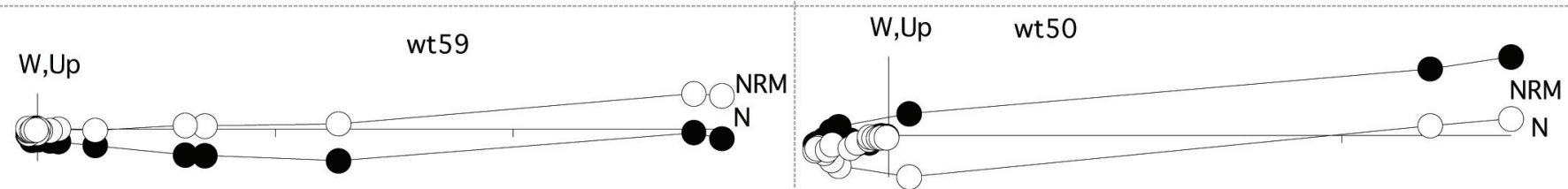

Tick $=100 \mathrm{~mA} / \mathrm{m}(\mathrm{V} / \mathrm{M}=10)$

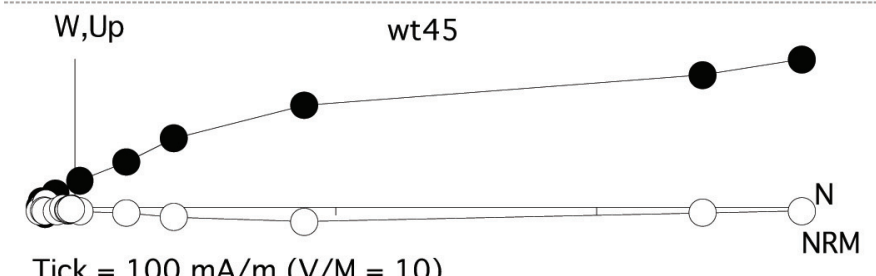

Tick $=100 \mathrm{~mA} / \mathrm{m}(\mathrm{V} / \mathrm{M}=10)$

Tick $=100 \mathrm{~mA} / \mathrm{m}(\mathrm{V} / \mathrm{M}=10)$

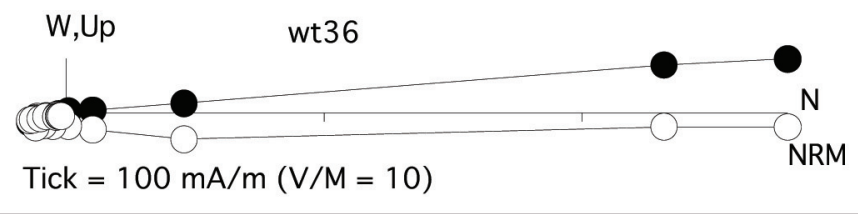

\section{b}

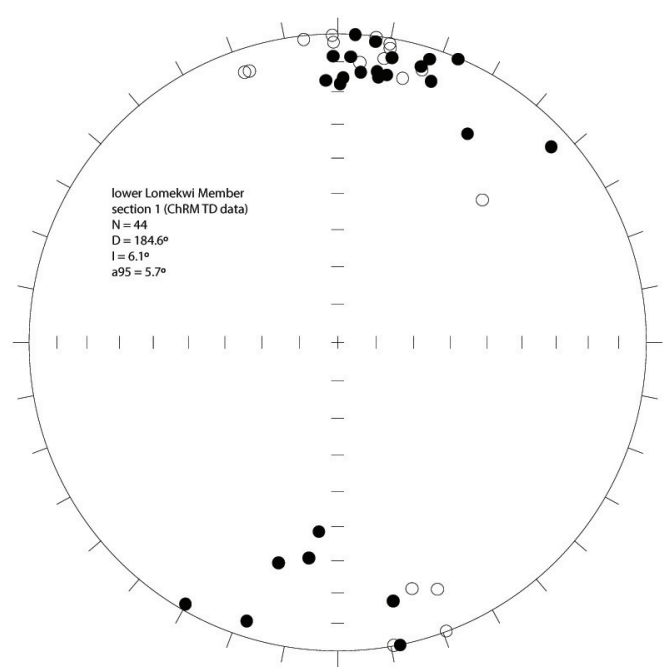

Extended Data Figure $3 \mid$ Paleomagnetic data. a, Representative vector endpoint plots of natural remanent magnetism thermal demagnetization data from specimen Toroto Tuff, tt2, wt59, wt50, wt 45 , wt36. Open and closed symbols represent the vertical and horizontal projections, respectively, in bedding coordinates. TD treatment steps: $\mathrm{NRM}, 100^{\circ}, 150^{\circ}, 200^{\circ}, 250^{\circ}, 300^{\circ}, 350^{\circ}, 400^{\circ}$, $450^{\circ}, 475^{\circ}, 500^{\circ}, 525^{\circ}, 550^{\circ}, 575^{\circ}, 600^{\circ}, 625^{\circ}, 650^{\circ}, 660^{\circ}, 670^{\circ}, 675^{\circ}, 680^{\circ}, 690^{\circ}$, and $700^{\circ} . \mathrm{V} / \mathrm{M}=10$ denotes $\mathrm{a} \sim 10 \mathrm{cc}$ cubic specimen. $\mathbf{b}$, Equal-area

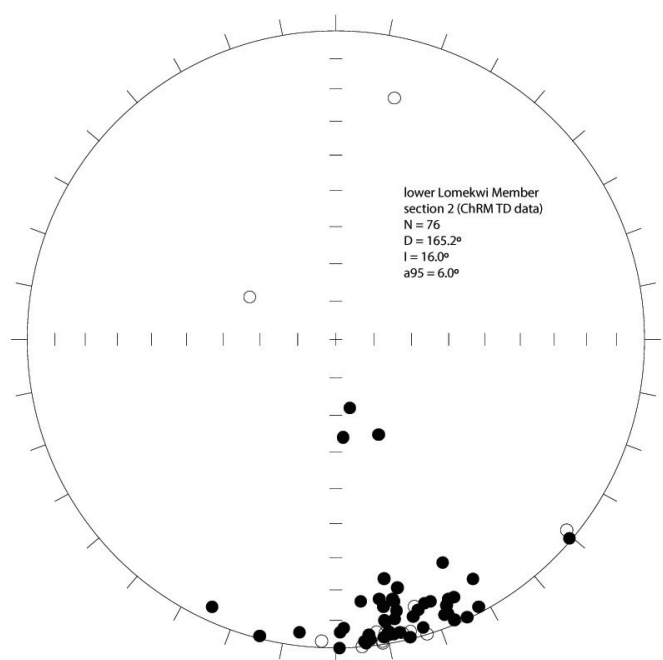

projections for Section 1 (left) and Section 2 (right) of the lower Lomekwi Member (see Fig. 3a). Open and closed symbols are projected onto the upper and lower hemisphere, respectively, in bedding coordinates. Plotted are ChRM sample-mean directions for accepted samples only (that is, those with MAD values $\left.<15^{\circ}\right)$. Overall mean directions were calculated after inverting the northerly (normal) directions to common southerly (reverse) polarity. 


\begin{tabular}{lcccc}
\hline Sample No. & $\begin{array}{c}\delta^{13} \mathrm{C}_{\mathrm{VPOB}} \\
(\%) \pm 1 \sigma\end{array}$ & $\begin{array}{c}\text { No. of } \\
\text { analyses }\end{array}$ & $f_{\mathrm{wc}}(\%)$ & $\begin{array}{c}\mathrm{C}_{4} \\
\text { biomass }(\%)\end{array}$ \\
\hline LOM-PC 4A* & $-7.4 \pm 1.6$ & 2 & 48 & 33 \\
LOM-PC 4B* & $-8.2 \pm 0.1$ & 2 & 54 & 27 \\
LOM-PC 4C* & $-9.4 \pm 0.2$ & 2 & 65 & 18 \\
LOM-PC 6A & $-8.2 \pm 0.5$ & 2 & 55 & 27 \\
LOM-PC 8A & $-6.2 \pm 0.2$ & 2 & 37 & 41 \\
LOM-PC 10A & $-7.2 \pm 0.2$ & 2 & 46 & 34 \\
LOM-PC 11/12A & $-7.9 \pm 0.2$ & 2 & 52 & 29 \\
LOM-PC 11/12B & $-7.6 \pm 0.3$ & 2 & 49 & 32 \\
LOM-PC 12A & $-7.7 \pm 0.0$ & 2 & 50 & 30 \\
LOM-PC 12/13A & $-6.2 \pm 0.5$ & 2 & 37 & 42 \\
LOM-PC 14A & $-7.4 \pm 0.2$ & 2 & 48 & 33 \\
LOM-PC 16A & $-6.7 \pm 0.4$ & 2 & 42 & 38 \\
LOM-PC 18A & $-7.1 \pm 0.0$ & 2 & 45 & 35 \\
LOM-PC 21A & $-6.9 \pm 0.3$ & 2 & 43 & 36 \\
LOM-PC 27A & $-4.7 \pm 0.6$ & 2 & 26 & 52 \\
LOM-PC 28A & $-7.7 \pm 0.3$ & 2 & 50 & 31 \\
LOM-PC 29A & $-7.8 \pm 0.2$ & 2 & 51 & 30 \\
LOM-PC 32A & $-4.9 \pm 0.2$ & 2 & 27 & 51 \\
LOM-PC 33A & -8.4 & 1 & 56 & 26 \\
LOM-PC 37A & $-7.2 \pm 0.2$ & 2 & 46 & 34 \\
LOM-PC 39A & $-7.1 \pm 1.1$ & 2 & 45 & 35 \\
LOM-PC 44A* & $-7.7 \pm 0.1$ & 2 & 50 & 30 \\
LOM-PC 44B* & $-6.8 \pm 0.1$ & 2 & 42 & 37 \\
LOM-PC 45A & $-8.7 \pm 0.1$ & 2 & 58 & 24 \\
\hline & & & &
\end{tabular}

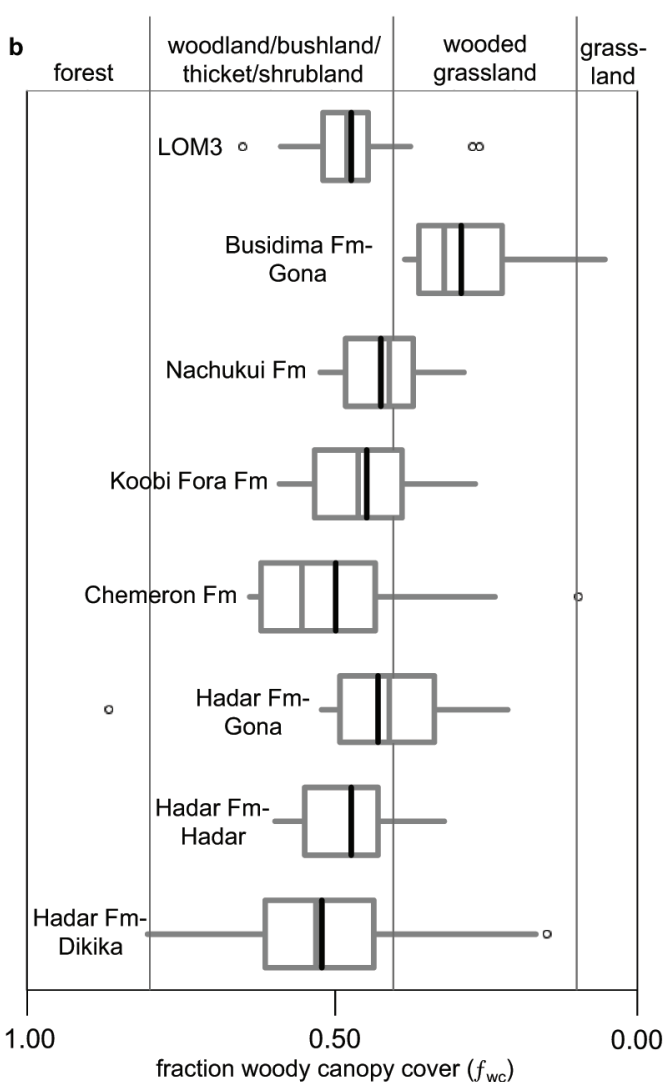

C

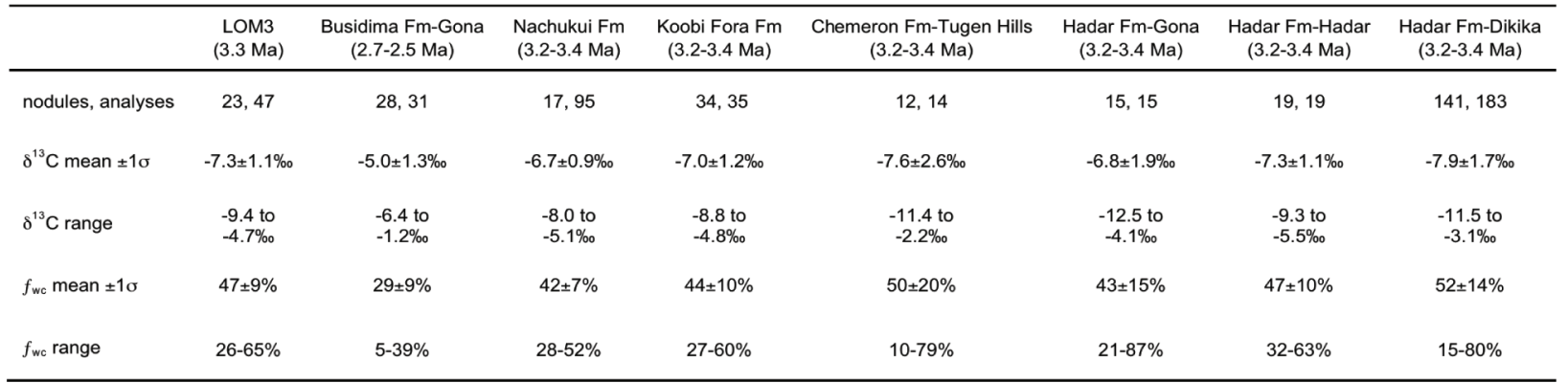

Extended Data Figure $4 \mid$ Paleoenvironmental reconstruction through pedogenic carbonate stable carbon isotopic analysis. a, LOM3 paleosol $\delta^{13} C_{\mathrm{VPDB}}$ values $(\%) \pm 1 \sigma$, number of analyses, fraction woody canopy cover $\left(f_{\mathrm{wc}}\right)$ and percent $\mathrm{C}_{4}$ biomass contribution to soil $\mathrm{CO}_{2}$. Asterisk denotes nodules sampled at the LOM3 site, 2011-2b (see Extended Data Fig. 2a). b, Schematic box and whisker plots of $f_{\mathrm{wc}}$ from the LOM3 (3.3 Ma, this study) and Gona ${ }^{33,54,55}$ (Busidima Fm, 2.5-2.7 Ma) lithic sites and other East African hominin localities from 3.2-3.4 $\mathrm{Ma}^{54-61}$ relative to UNESCO structural categories of African vegetation ${ }^{32,52}$. Grey box denotes 25 th and 75 th percentiles (interquartile range); whiskers represent observations within upper and lower fences $(1.5 \times$ interquartile range); black line shows mean value; grey line equals median value; black circles indicate mild outliers. c, Summary statistics of paleosol $\delta^{13} \mathrm{C}_{\mathrm{VPDB}}$ values and $f_{\mathrm{wc}}$ from LOM3 (3.3 Ma) and Gona ${ }^{33,54,55}$ (2.5-2.7 Ma) lithic sites and other East African hominin localities from 3.2-3.4 Ma ${ }^{54-61}$. LOM3 $\delta^{13} \mathrm{C}_{\mathrm{VPDB}}$ values are significantly lower than those from the Busidima Formation at Gona $(t$-test, $P<0.001)$ and have a mean value that indicate $18 \%$ more woody canopy cover. When compared to paleosol $\delta^{13} \mathrm{C}_{\mathrm{VPDB}}$ values of the Koobi Fora, Nachukui, Chemeron, and Hadar formations from 3.2 to $3.4 \mathrm{Ma}$, LOM3 $\delta^{13} \mathrm{C}_{\mathrm{VPDB}}$ values are not significantly different (one-way ANOVA, $P>0.05$ ). 

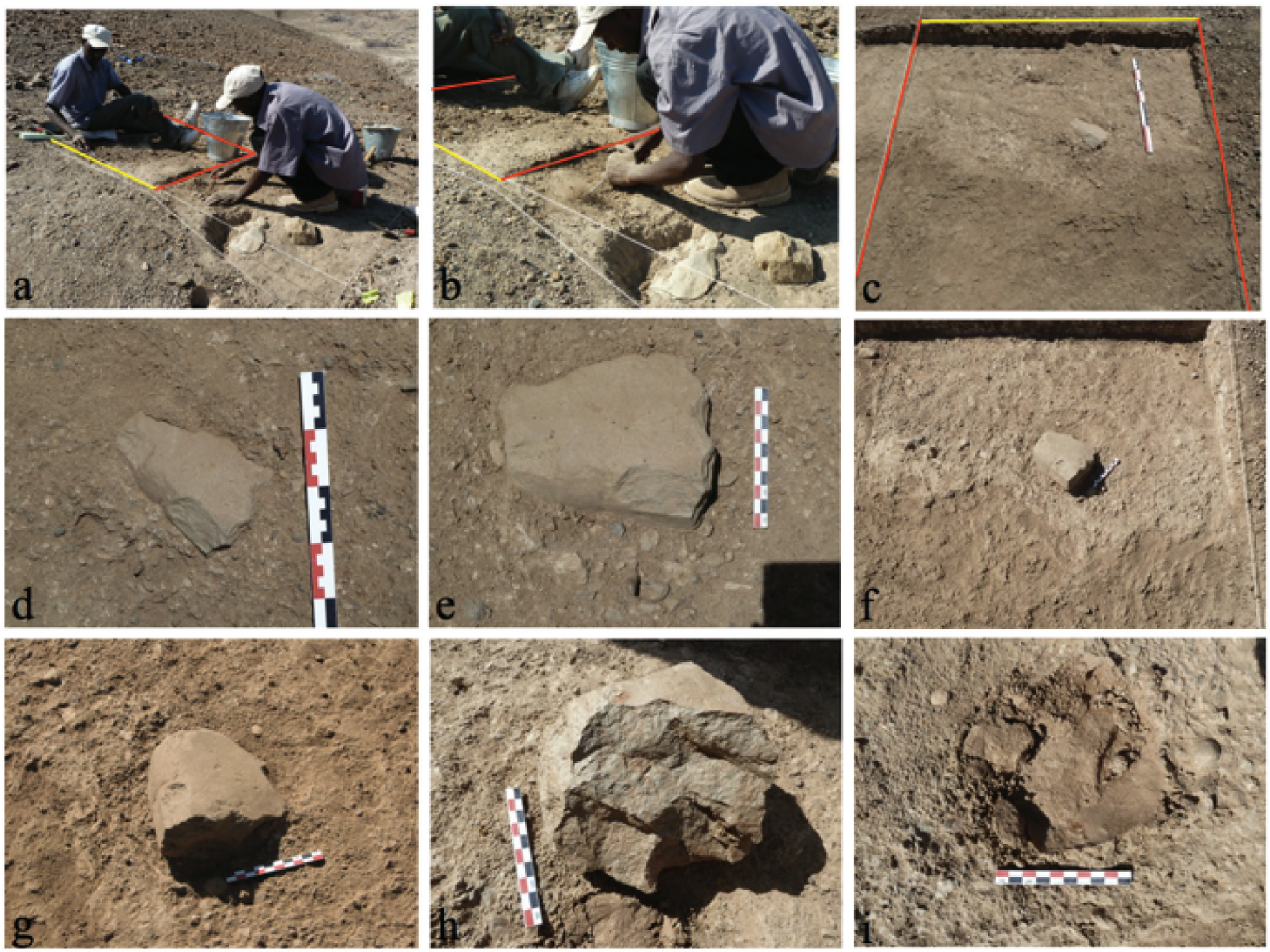

Extended Data Figure 5 | Gradual uncovering of core I16-3 from in situ pliocene sediment. a, Photograph showing square I16 at the beginning of excavation. Yellow line indicates north wall of square (July 16, 2011, 12.14 p.m.). b, Close-up of square I16 indicating complete burial of as-yet-uncovered artefact I16-3 (12.14 p.m.). c, Square I16 after excavation had begun and artefact I16-3 was initially exposed (2:11 p.m.). d, Close-up of artefact I16-3 after being initially exposed (2.12 p.m.). e, Close-up of artefact I16-3 after further excavation (3.02 p.m.). f, Square I16 after further excavation (5.32 p.m.). g, Close-up of artefact I16-3 after further excavation (5.34 p.m.). h, Close-up of artefact I16-3 after being completely freed from the surrounding matrix and flipped over for inspection (5.36 p.m.). i, Close-up of impression from under artefact I16-3 (5.47 p.m.). 
a

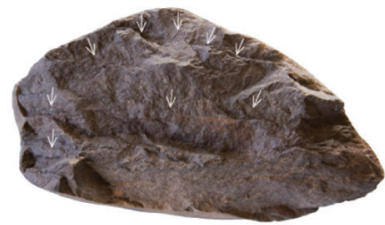

I

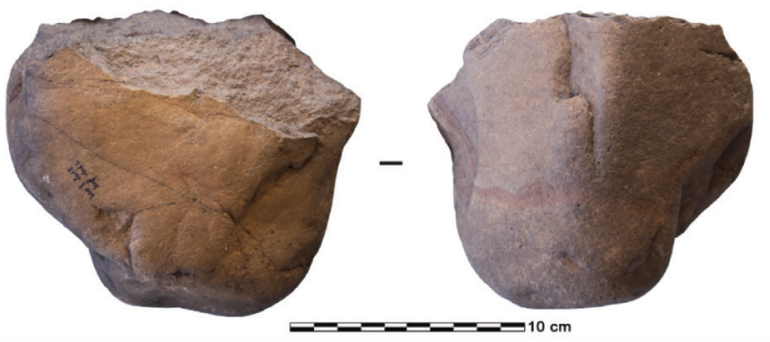

b

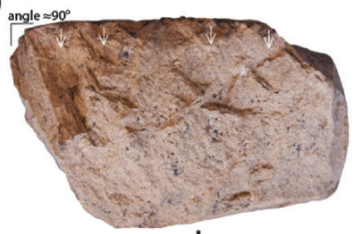

I

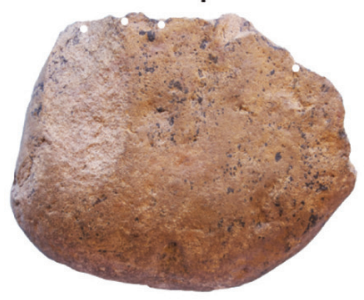

- $=-1=-10 \mathrm{~cm}$

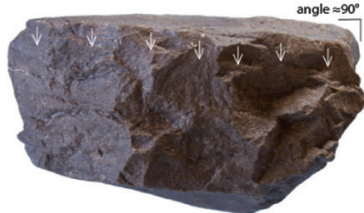

I

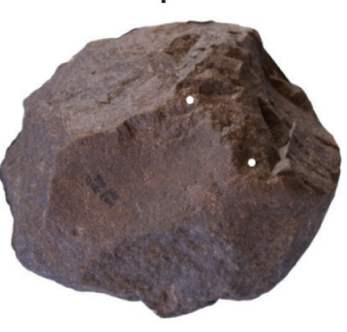

-

Extended Data Figure $6 \mid$ Photos of selected LOM3 artefacts compared with similar experimental cores. Together with the technological analysis of the archaeological material, our replication experiments suggest that the LOM3 knappers were using passive hammer technique, in which the core, usually held in both hands, is struck against a stationary object that serves as the percussor ${ }^{34}$ (also referred to as on-anvil, block on block or sur percuteur dormant ${ }^{35}$ ) and/or bipolar technique, in which the core is placed on an anvil and struck with a hammerstone ${ }^{34}$. a, Unifacial passive hammer cores. Left is archaeological piece LOM3-2012 surf 106 (2.04 kg); right is experimental piece Expe 55 (3.40 kg) produced using the passive hammer technique. Selection of relatively flat blocks with natural obtuse angles. The flake removal process starts from a slighly prominent part of the block (white arrows show the direction of removals). The
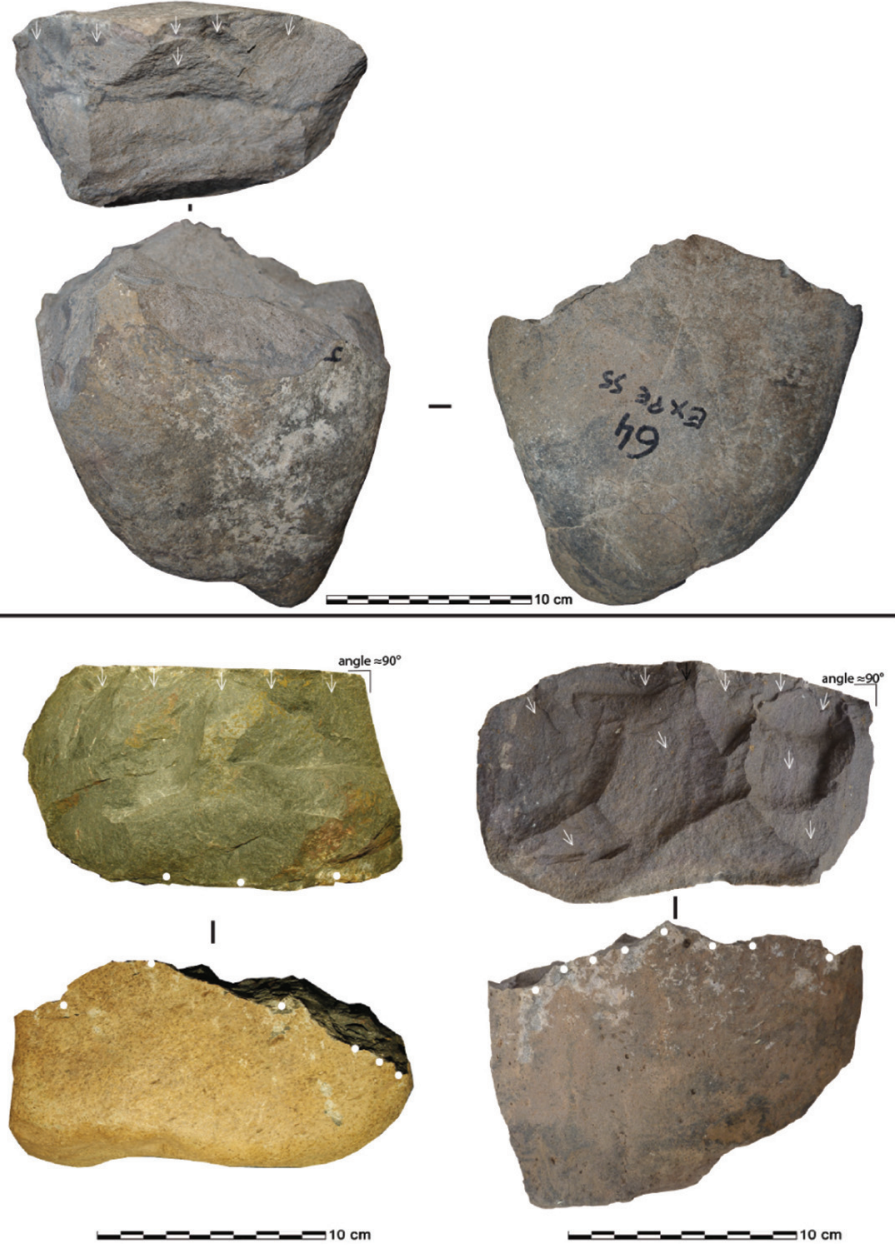

- - - - $10 \mathrm{~cm}$

removals tend to be invasive. The flaked surface forms a semi-abrupt angle with the platform surface. A slight rotation of the block ensures its semi-peripheral exploitation. b, Unifacial bipolar cores. Left are archaeological pieces LOM32012-H18-1 (left, $3.45 \mathrm{~kg}$ ) and LOM3-2012 surf 64 (right, $2.58 \mathrm{~kg}$ ); right are experimental pieces Expe 39 (left, $4.20 \mathrm{~kg}$ ) and Expe 24 (right, $2.23 \mathrm{~kg}$ ) produced using the bipolar technique. The block selected are thicker and more quadrangular in shape with natural angles $\approx 90^{\circ}$. Flakes are removed from a single secant platform (white arrows show the direction of removals). The flaked surface forms an abrupt angle with the other faces of the block. Impacts due to the contrecoups (white dots) are visible on the opposite edge from the platform. 

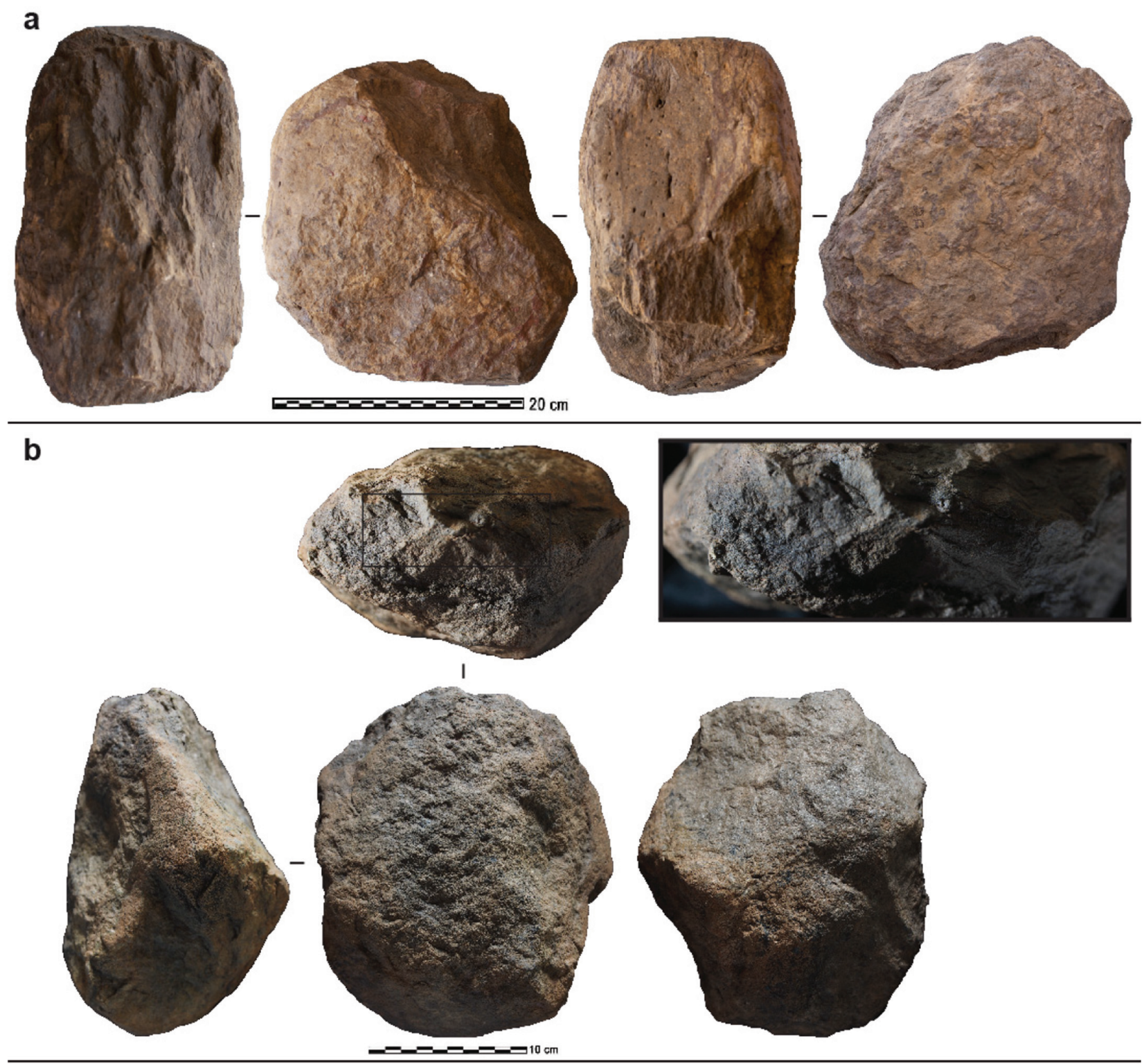

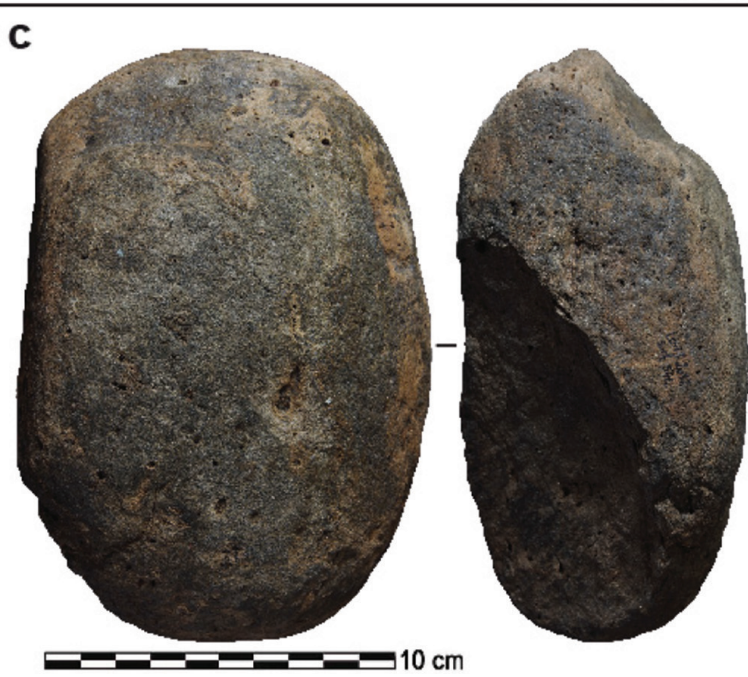

Extended Data Figure $7 \mid$ Photographs of selected LOM3 artefacts. a, Passive element/anvil (LOM3-2012 surf 50,15 kg). Heavy sub-rectangular block displaying flat faces and therefore a natural morphology and weight which would enable stability. b. Hammerstone showing isolated impact points

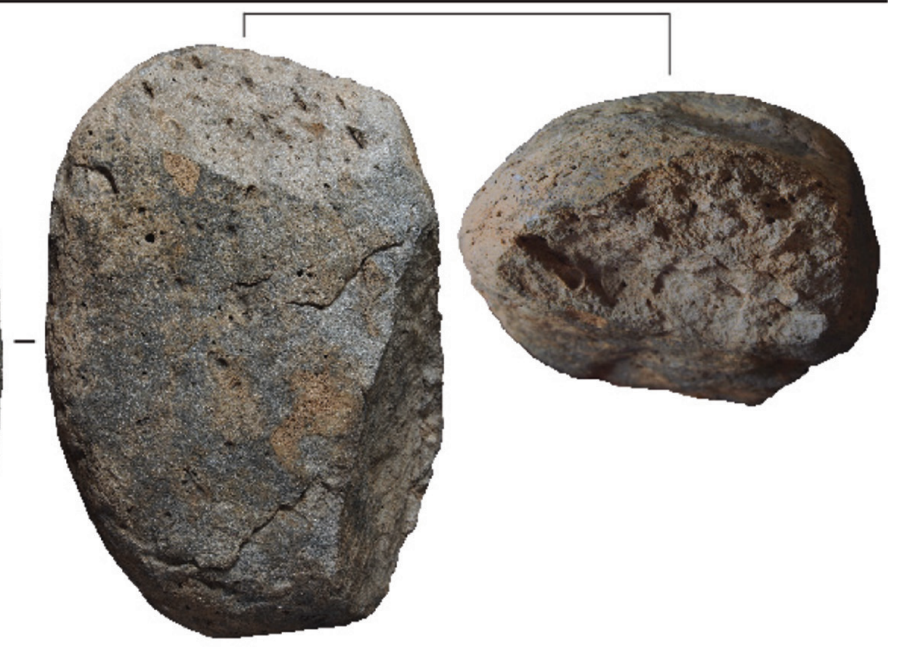

(LOM3-2012 surf 33, $3.09 \mathrm{~kg}$ ) and c, Hammerstone showing isolated impact points (LOM3-2012 surf 54, $1.63 \mathrm{~kg}$ ), associated with a flake-like fracture on one end. 


\section{RESEARCH ARTICLE}

Extended Data Table 1 | Numerical data on the LOM3 lithic assemblage (2011, 2012).

a

\begin{tabular}{|c|c|c|c|c|c|}
\hline ARTEFACTS & & in situ & $\begin{array}{c}\text { slope } \\
\text { deposit }\end{array}$ & surface & total \\
\hline \multirow{5}{*}{ core } & passive hammer technique & 1 & 1 & 33 & 35 \\
\hline & bipolar technique & 2 & 3 & 26 & 31 \\
\hline & $\begin{array}{l}\text { passive hammer and/or freehand } \\
\text { technique }\end{array}$ & 0 & 0 & 6 & 6 \\
\hline & bipolar and/or passive hammer technique & 2 & 0 & 4 & 6 \\
\hline & of indeterminate technique & 1 & 0 & 4 & 5 \\
\hline flake, whole or broken & & 10 & 3 & 22 & 35 \\
\hline percussor, whole, broken or potential & & 0 & 0 & 7 & 7 \\
\hline passive element/potential anvil & & 2 & 1 & 4 & 7 \\
\hline worked cobble & & 0 & 0 & 3 & 3 \\
\hline split cobble & & 0 & 0 & 2 & 2 \\
\hline fragment indet. & & 1 & 2 & 4 & 7 \\
\hline indet. & & 0 & 0 & 5 & 5 \\
\hline total & & 19 & 10 & 120 & 149 \\
\hline
\end{tabular}

b

\begin{tabular}{lcc}
\hline RAW MATERIAL & $\mathrm{N}$ & $\%$ \\
\hline phonolite & 51 & 34.23 \\
trachy-phonolite & 35 & 23.49 \\
basalt & 52 & 34,90 \\
trachyte & 2 & 1.34 \\
vesicular basalt/conglomerate & 3 & 2.01 \\
indet. & 6 & 4.03 \\
total & 149 & 100.00 \\
\hline
\end{tabular}

a, Initial categorisation of the lithic components. b, Breakdown of lithic raw materials in the LOM3 assemblage. 
Extended Data Table 2 | Comparison of whole flake and core dimensions between LOM3, early Oldowan sites and chimpanzee stone tool sites

\begin{tabular}{|c|c|c|c|c|c|c|c|c|c|c|c|c|c|c|c|c|c|}
\hline \multirow[b]{2}{*}{ Site } & \multirow[b]{2}{*}{ Age (Ma) } & \multirow[b]{2}{*}{ Ref. } & \multicolumn{4}{|c|}{ Length } & \multicolumn{4}{|c|}{ Width } & \multicolumn{5}{|c|}{ Thickness } & \multirow[b]{2}{*}{ Geo. Mean } & \multirow[b]{2}{*}{ Mean Mass } \\
\hline & & & $\mathrm{N}$ & Mean & Std & Min & Max & Mean & Std & Min & Max & Mean & Std & Min & Max & & \\
\hline \multicolumn{18}{|c|}{ FLAKES } \\
\hline LOM3 & 3.3 & & 26 & 120 & 48.8 & 19 & 205 & 110.1 & 40.7 & 19 & 185 & 43.9 & 23.4 & 6 & 90 & 59.9 & $842.4(\mathrm{~N}=26)$ \\
\hline OGS7 & 2.6 & 62 & 73 & $39.1^{*}$ & 14.3 & 13 & 80 & $37.1^{*}$ & 14.1 & 13 & 74 & $12.7^{*}$ & 5.07 & 3 & 26 & 14.10 & $18.9(\mathrm{~N}=76)^{\ddagger}$ \\
\hline EG10 & 2.6 & 62 & 114 & $37.38^{*}$ & 15.34 & 14 & 78 & $34.63^{*}$ & 13.74 & 14 & 78 & $13.18^{*}$ & 6.26 & 3 & 33 & 13.74 & $24.9(\mathrm{~N}=72)^{\ddagger}$ \\
\hline EG12 & 2.6 & 62 & 62 & $34.5^{\star}$ & 12.84 & 15 & 66 & $35.55^{*}$ & 13.23 & 19 & 66 & $12.13^{*}$ & 5.76 & 4 & 30 & 13.23 & $21.5(\mathrm{~N}=61)^{\ddagger}$ \\
\hline AL894 & 2.36 & $63^{\dagger}$ & 1048 & $35.9^{*}$ & 23.63 & 6 & 134 & $25.07^{*}$ & 17.57 & 2 & 106 & $7.98^{\star}$ & 6.4 & 1 & 45 & 17.1 & \\
\hline LA2C & 2.34 & 16 & 500 & $38^{*}$ & 15 & 12 & 96 & $35^{*}$ & 14 & 7 & 128 & $11^{*}$ & 5 & 3 & 28 & 14.00 & \\
\hline Omo57 & 2.34 & $14^{\dagger}$ & 44 & $24.75^{\star}$ & 10.546 & 10 & 58 & $20.36^{*}$ & 6.851 & 10 & 44 & $7.73^{*}$ & 4.008 & 1 & 18 & 6.85 & \\
\hline Omo123 & 2.34 & $14^{\dagger}$ & 110 & $20.8^{*}$ & 7.495 & 7 & 50 & $17.79^{\star}$ & 6.485 & 6 & 38 & $5.9^{*}$ & 2.792 & 1 & 16 & 6.49 & \\
\hline DK & $>1.84$ & 64 & 115 & $40.18^{*}$ & 14.803 & 18 & 111 & $37.41^{*}$ & 11.215 & 17 & 71 & $11.89^{*}$ & 5.404 & 4 & 29 & 11.22 & \\
\hline FLKZinj & $1.76-1.84$ & 64 & 125 & $36.78^{*}$ & 12.13 & 16 & 82 & $32.88^{*}$ & 11.59 & 4 & 76 & $11.51^{*}$ & 5.45 & 4 & 36 & 11.59 & \\
\hline Noulo & .0043 & 40 & 5 & $35^{*}$ & 20.62 & 15 & 70 & $48^{*}$ & 27.06 & 15 & 90 & $11.6^{*}$ & 3.21 & 8 & 15 & 20.15 & \\
\hline \multicolumn{18}{|c|}{ CORES } \\
\hline LOM3 & 3.3 & & 83 & 167 & 23.4 & 132 & 260 & 147.8 & 23.1 & 90 & 210 & 108.8 & 21.8 & 61 & 170 & 139 & $3096.4(\mathrm{~N}=81)$ \\
\hline OGS7 & 2.6 & 62 & 7 & $44.14^{*}$ & 13.68 & 28 & 67 & $59^{*}$ & 8.54 & 45 & 70 & $37^{\star}$ & 8.2 & 22 & 49 & 45.85 & $78^{\ddagger}$ \\
\hline EG10 & 2.6 & 62 & 16 & $83.33^{*}$ & 10.34 & 69 & 105 & $60.9^{*}$ & 9.18 & 44 & 80 & $45.27^{*}$ & 12.36 & 30 & 69 & 61.25 & $232^{\ddagger}$ \\
\hline EG12 & 2.6 & 62 & 7 & $74.45^{*}$ & 8.72 & 58 & 93 & $59.73^{*}$ & 8.06 & 49 & 77 & $43.73^{*}$ & 77.4 & 25 & 53 & 57.94 & $194(\mathrm{~N}=9)^{\ddagger}$ \\
\hline AL894 & 2.36 & $63^{\dagger}$ & 38 & $75.01^{*}$ & 30.32 & 19.31 & 136.3 & $55.33^{*}$ & 22.54 & 12.21 & 94.9 & $35.87^{*}$ & 18.1 & 7.92 & 78.2 & 53.00 & \\
\hline LA2C & 2.34 & 16 & 70 & $66^{*}$ & 18 & 39 & 123 & $52^{*}$ & 14 & 32 & 95 & $32^{*}$ & 12 & 12 & 78 & 47.9 & \\
\hline Omo 57 & 2.34 & $14^{\dagger}$ & 7 & $37.4^{*}$ & 8.81 & 25 & 52 & $28.8^{*}$ & 7.313 & 22 & 40 & $16.5^{*}$ & 4.721 & 11 & 24 & 26.10 & \\
\hline Omo 123 & 2.34 & $14^{\dagger}$ & 11 & $30.5^{*}$ & 12.193 & 17 & 56 & $22.27^{*}$ & 8.186 & 13 & 42 & $13.5^{*}$ & 4.569 & 9 & 24 & 20.93 & \\
\hline DK & $>1.84$ & 64 & 69 & $67.93^{*}$ & 19.146 & 30 & 117 & $62.78^{*}$ & 17.992 & 25 & 100 & $48.25^{*}$ & 14.435 & 18 & 81 & 59.04 & \\
\hline FLK Zinj (lava only) & $1.76-1.84$ & 64 & 49 & $76.35^{*}$ & 12.57 & 53 & 95 & $78.85^{*}$ & 16.26 & 49 & 112 & $59^{\star}$ & 12.3 & 37 & 87 & 70.82 & \\
\hline
\end{tabular}

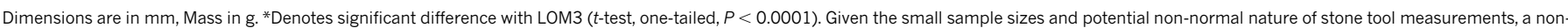

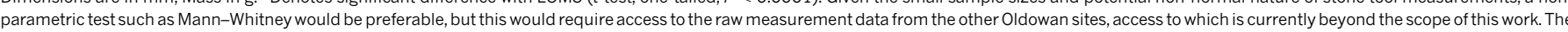
Student's $t$-test is very robust, however, as deviations from normality do not affect it very much, and it is currently the only option when working with published data summaries.

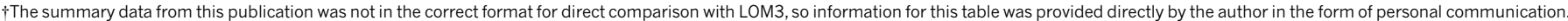
Data from ref. 17, hence differing sample sized from ref. 62

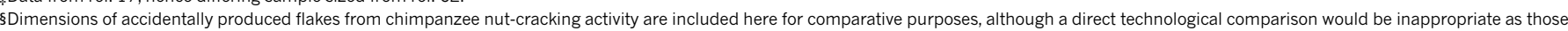
pieces are not the result of intentional flake manufacture and do not bear the classic technological flake characteristics like those from LOM3 and early Oldowan sites. 


\section{RESEARCH ARTICLE}

Extended Data Table 3 | Comparison of anvils and percussors dimensions found at LOM3 site with anvils and percussors used by non-human primates in Bossou (wild chimpanzees, Pan troglodytes verus from ref. 41)

\begin{tabular}{|c|c|c|c|c|c|c|c|c|c|}
\hline & & \multicolumn{2}{|c|}{ Length } & \multicolumn{2}{|c|}{ Width } & \multicolumn{2}{|c|}{ Thickness } & \multicolumn{2}{|c|}{ Mass } \\
\hline Site & $\mathrm{N}$ & Mean & Std & Mean & Std & Mean & Std & Mean & Std \\
\hline \multicolumn{10}{|c|}{ ANVILS } \\
\hline LOM3 & 7 & 19.40 & \pm 6.26 & 15.44 & \pm 3.69 & 12.54 & \pm 3.17 & 6511.29 & \pm 4901.64 \\
\hline BOSSOU & 32 & 16.10 & \pm 6.47 & $11.1^{*}$ & \pm 4.38 & $7.30^{*}$ & \pm 2.97 & $2200.00^{* \dagger}$ & \pm 2210.00 \\
\hline \multicolumn{10}{|c|}{ PERCUSSORS } \\
\hline LOM3 & 7 & 13.38 & \pm 3.67 & 10.75 & \pm 2.81 & 7.84 & \pm 2.33 & 1602.00 & \pm 1120.55 \\
\hline BOSSOU & 35 & 12.00 & \pm 2.65 & $7.70^{*}$ & \pm 1.86 & $5.20^{*}$ & \pm 1.08 & $700.00^{*}$ & \pm 330.00 \\
\hline
\end{tabular}

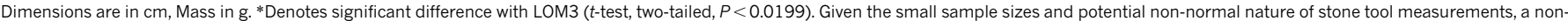

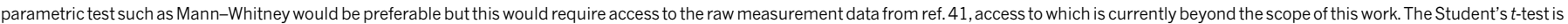
very robust, however, as deviations from normality do not affect it very much and it is currently the only option when working with published data summaries.

$\dagger N=31$ 